\title{
Diversity, trait preferences, management and utilization of yams landraces (Dioscorea species): an orphan crop in DR Congo
}

Idris I Adejumobi

International Institute of Tropical Agriculture

\section{Paterne AGRE ( $\sim$ P.Agre@cgiar.org )}

IITA: International Institute of Tropical Agriculture https://orcid.org/0000-0003-1231-2530

Didy 0. Anautshu

University of Kisangani: Universite de Kisangani

Joseph G. Adheka

University of Kisangani: Universite de Kisangani

Mokonzi G. Banbanota

University of Kisangani: Universite de Kisangani

Jean-Claude L. Mozenga

University of Kisangani: Universite de Kisangani

Joseph L. Komoy

University of Kisangani: Universite de Kisangani

Inacio M. Cipriano

University of Kisangani: Universite de Kisangani

\section{Research}

Keywords: Dioscorea, DR Congo, Famers' preference criteria, Landrace diversity, Yam

Posted Date: August 4th, 2021

DOI: https://doi.org/10.21203/rs.3.rs-753319/v1

License: (c) (1) This work is licensed under a Creative Commons Attribution 4.0 International License. Read Full License

Version of Record: A version of this preprint was published at Scientific Reports on February 10th, 2022. See the published version at https://doi.org/10.1038/s41598-022-06265-w. 


\section{Abstract}

Background

Yam ( Dioscorea spp .) is cultivated in many villages of DR Congo as a means to sustain food security and alleviate poverty. However, the extent of the existing diversity has not been studied in details thus, considered as an orphan.

Methodology

A survey covering 540 farmers in 54 villages was conducted in six major yam growing territories covering three provinces in DR Congo to investigate the diversity, management and utilization of yam landraces using pre-elaborate questionnaires.

Results

Subject to synonymy, a total of 67 landraces clones from five different species were recorded. Farmers' challenges limiting yam production were poor tuber qualities (69\%), harvest pest attack (7\%), difficulty in harvesting (6\%), poor soil status (6\%). The overall diversity was moderate among the recorded yam germplasm maintained at the household level (1.32) and variability exist in diversity amongst the territories and provinces. Farmers' in territories of Tshopo and Mongala provinces maintained higher level of germplasm diversity (2.79 and 2.77) compared to the farmers in territories of Bas-Uélé (1.67). Some yam landraces had limited abundance and distribution due to loss of production interest in many villages attributable to poisons contained hence, resulting in possible extinction. Farmers' most preferred seed source for cultivation were backyard (43\%) and exchange with neighboring farmers (31\%) with the objective of meeting food security and generating income. In villages where yam production is expanding, farmers are relying on landraces with good tuber qualities and high yield even though they are late maturing.

Conclusion

This study revealed the knowledge of yam genetic diversity, constraints to production and farmers' preferences criteria as a guide for collection and conservation of yam genetic resources for yam improvement intervention.

\subsection{Introduction}

Yam is a crop of major economic and cultural importance in sub-Saharan Africa where about $95 \%$ of the global production resides [1]-[4]. The yam belt of West and Central Africa is identified to be the principal areas of production [2], [5], [6]. The importance of yam has been reported in ensuring food security and enhancing livelihood systems of millions of people in sub-Saharan Africa [7]. Yam as food source and cash crop has been understudied and underutilized and mostly referred to as orphan crop by researchers [8], [9]. However, following the establishment of research institutions such as the International Institute of Tropical Agriculture (IITA), yam has gained substantial research attention in recent decades [10]. Thus, substantial progress has been made in understanding the origin, domestication, phylogeny, diversity and production of yam [10]-[13].

The substantial research attention gained by yam has however not included the yam genetic resources in DR Congo being a major country in the Central African territory. Hence, little is known about the status of yams in DR Congo compared to other Central and sub-Saharan African countries. This has led to the perception that yam is not an important food crop in the DR Congo. Studies into genetic diversity and selection have mainly focused on

Page 2/34 
cereals [14]-[16] and cassava [17], [18] in the country. Consequently increasing their adoption and productivity while yams that is native to the country [19] with significant level of consumption have been neglected.

Yams are hardly known to the scientific community in DR Congo and in most cases referred to as orphan crop as no one cares for the existence. There has been no systematic study on diversity, production and use of yams in DR Congo. Although brief and passing remarks are available in the more general references [20]-[22]. Magwe'-Tindo et al. reported DR Congo as one of the countries with high diversity of wild yam alongside some other Central African and West African countries. Siqueira et al. reported the DNA fingerprinting performance of the Dioscorea alata landrace genotype locally called "Bira" in Brazil. This landrace genotype was introduced into the Brazilian genetic resources from DR Congo alongside other genotypes from other regions. Bukatuka et al. reported the performance of five Dioscorea species (D. alata, D. bulbifera, D. dumetorum, D. burkilliana, and D. praehensilis) with respect to bioactivity and nutritional values. These authors concluded that the studied species showed good antioxidant and anti- hyperglycemic properties as well as high nutritive value. Thus, could be promoted as functional foods in DR Congo. These reports indicate that yam is widely cultivated in DR Congo, and is amongst the main root and tuber crops grown by subsistence farmers in the forest zone regions of the country.

However, the extent and distribution of the available inter and intraspecific diversity is poorly investigated. In situations where documented data are hardly available as the case in DR Congo, the local farmer is the first source of information to initiate diversity studies. Farmers' perception of local varieties is of utmost importance because it is not only the unit of diversity they recognize but also the unit they actually manage and conserve [23]. Following previous findings [20], it is worth understanding the genetic diversity of yam species (cultivated and wild relatives) in DR Congo to guide possible future collection and conservation of yam genetic resources as well as provide useful information for future yam improvement program in the country. This study forms part of a larger objective to characterize yam genetic diversity in DR Congo. It aims to investigate the diversity of yam landraces in Bas-Uélé, Mongala and Tshopo provinces and to describe how the landraces varieties are selected, managed and utilized by local farmers.

\subsection{Materials And Methods}

\subsection{Description of study area}

Three Administration provinces (using the modern map) constituting six territories: Bas-Uélé (Bambesa and Buta territories), Mongala (Bumba and Lisala territories), and Tshopo (Kisangani and Isangi territories) represented the study areas (Figure 1). Bas-Uélé province lies in the north-east of the DR Congo map on the Uélé river bordered by the provinces of Haut-Uélé to the east, Nord-Ubangi and Mongala to the west and Tshopo to the south. Mongala is located at the northwest of the country on the Congo River, and borders the provinces of Tshopo and Bas-Uélé (east), Nord-Ubangi (north), Sud-Ubangi and Équateur (west) and Tshuapa (south). Tshopo province is located at the northcentral part of the country on the Congo river, and bordered by the provinces of Bas-Uélé, Haut-Uélé, Mongala, Ituri, Nord-Kivu, Maniema, Tshuapa and Sankuru. Bas-Uélé province is characterized by the forest and savannah vegetation while Tshopo and Mongala provinces are characterized by the forest vegetation. Rainfall pattern is all year round and the forest vegetation forms the largest part of the vegetation in DR Congo where majority of the farming activities occur. The major food crops cultivated across the study areas include cereals (maize, rice etc.), root and tubers (cassava, yam, potatoes etc.), legumes (cowpea, pigeon pea etc.), oilseeds (peanut and soya) and fruits (banana and plantain) (Table 1). Yam is locally called "Mboma" in Lingala language and "Biama" in Swahili language. These two languages form the major dialects in the study areas. 
Table 1. Ecological characteristics of the survey regions

\begin{tabular}{|c|c|c|c|c|c|c|c|}
\hline Province & Territory & $\begin{array}{l}\text { Coordinates } \\
\text { (lat., long.) }\end{array}$ & $\begin{array}{l}\text { Elevation } \\
\text { (meters) }\end{array}$ & $\begin{array}{l}\text { Mean } \\
\text { Rainfall } \\
\text { (mm/year) }\end{array}$ & $\begin{array}{l}\text { Mean } \\
\text { Temperature } \\
\left({ }^{\circ} \mathrm{C}\right)\end{array}$ & $\begin{array}{l}\text { Vegetation } \\
\text { type }\end{array}$ & $\begin{array}{l}\text { Crops } \\
\text { cultivation }\end{array}$ \\
\hline \multirow[t]{2}{*}{ Bas-Uélé } & Bambesa & $\begin{array}{l}3.44^{\circ} \mathrm{N} \\
25.69^{\circ} \mathrm{E}\end{array}$ & 415 & 1,716 & $\begin{array}{l}\text { Min }=19 \\
\quad \operatorname{Max}=37\end{array}$ & \multirow[t]{2}{*}{$\begin{array}{l}\text { Dense } \\
\text { humid } \\
\text { forest, } \\
\text { Secondary } \\
\text { forest, } \\
\text { Forest } \\
\text { galleries, } \\
\text { Wooded } \\
\text { savannah }\end{array}$} & \multirow{2}{*}{$\begin{array}{l}\text { Cereals } \\
\text { (Maize, Rice, } \\
\text { Millet and } \\
\text { Sorghum); } \\
\text { Root and } \\
\text { Tubers } \\
\text { (Manioc, Yam, } \\
\text { Potatoes and } \\
\text { Taro); } \\
\text { Legumes } \\
\text { (Bean, } \\
\text { Cowpea and } \\
\text { Peas); } \\
\text { Oilseeds } \\
\text { (Peanut and } \\
\text { Soya); } \\
\text { Fruits (Banana } \\
\text { and Plantain) }\end{array}$} \\
\hline & Buta & $\begin{array}{l}2.81^{\circ} \mathrm{N} \\
24.75^{\circ} \mathrm{E}\end{array}$ & 430 & 2,374 & $\begin{array}{l}\text { Min }=20 \\
\quad \operatorname{Max}=37\end{array}$ & & \\
\hline \multirow[t]{2}{*}{ Mongala } & Bumba & $\begin{array}{l}2.20^{\circ} \mathrm{N} \\
22.47^{\circ} \mathrm{E}\end{array}$ & 409 & 2,424 & $\begin{array}{l}\operatorname{Min}=21 \\
\quad \operatorname{Max}=37\end{array}$ & \multirow[t]{2}{*}{$\begin{array}{l}\text { Dense } \\
\text { humid } \\
\text { forest, } \\
\text { Secondary } \\
\text { forest, } \\
\text { Edaphic } \\
\text { Forest }\end{array}$} & \multirow{2}{*}{$\begin{array}{l}\text { Cereals } \\
\text { (Maize, Rice, } \\
\text { Millet and } \\
\text { Sorghum); } \\
\text { Root and } \\
\text { Tubers } \\
\text { (Manioc, Yam, } \\
\text { Potatoes and } \\
\text { Taro); } \\
\text { Legumes } \\
\text { (Bean, } \\
\text { Cowpea and } \\
\text { Peas); } \\
\text { Oilseeds } \\
\text { (Peanut and } \\
\text { Soya); Fruits } \\
\text { (Banana and } \\
\text { Plantain) }\end{array}$} \\
\hline & Lisala & $\begin{array}{l}2.17^{\circ} \mathrm{N} \\
21.49^{\circ} \mathrm{E}\end{array}$ & 418 & 2,340 & $\begin{array}{l}\operatorname{Min}=21 \\
\quad \operatorname{Max}=37\end{array}$ & & \\
\hline \multirow[t]{3}{*}{ Tshopo } & Kisangani & $\begin{array}{l}0.52^{\circ} \mathrm{N} \\
25.20^{\circ} \mathrm{E}\end{array}$ & 447 & 3,156 & $\begin{array}{l}\text { Min }=21 \\
\quad \operatorname{Max}=39\end{array}$ & \multirow[t]{3}{*}{$\begin{array}{l}\text { Dense } \\
\text { humid } \\
\text { forest, } \\
\text { Secondary } \\
\text { forest, } \\
\text { Edaphic } \\
\text { Forest }\end{array}$} & \multirow{2}{*}{$\begin{array}{l}\text { Cereals } \\
\text { (Maize, Rice, } \\
\text { Millet and } \\
\text { Sorghum); } \\
\text { Root and } \\
\text { Tubers } \\
\text { (Manioc, Yam, } \\
\text { Potatoes and } \\
\text { Taro); } \\
\text { Legumes } \\
\text { (Bean, } \\
\text { Cowpea and } \\
\text { Peas); } \\
\text { Oilseeds } \\
\text { (Peanut and } \\
\text { Soya); }\end{array}$} \\
\hline & Isangi & $\begin{array}{l}0.78^{\circ} \mathrm{N} \\
24.27^{\circ} \mathrm{E}\end{array}$ & 435 & 2,258 & $\begin{array}{l}\operatorname{Min}=21 \\
\quad \operatorname{Max}=35\end{array}$ & & \\
\hline & & & & & & & $\begin{array}{l}\text { Fruits (Banana } \\
\text { and Plantain) }\end{array}$ \\
\hline
\end{tabular}


Source: National Agency for the Promotion of Investments (DR Congo); World Weather online (https://www.worldweatheronline.com)

\subsection{Sampling technique and data collection}

Prior to the survey, the Inspection Provinciale de l'Agriculture, Kisangani, Tshopo province was visited. Discussion was held with the Province Agricultural Inspector (Augustine Emmanuel Milabo Likele) to identify the major yam production areas in DR Congo. A total of nine provinces with significant level of production (greater than 10,000 tons) were identified using the national statistical data on yam released for the year 2015 [24] . Of this nine provinces, three were selected for the survey (Bas-Uélé, Mongala and Tshopo). In each province, two territories were selected for the study giving a total of six territories. In each territory, nine villages were selected giving a total of fifty-four villages used for this study. Per village, a total of 10 farm families were surveyed and their farms were visited for observation on the type of yam species being cultivated following the willingness of the farmers. A total of 540 farmers who cultivate yam either as sole-cropping or intercropped with other crops were individually interviewed using a pre-elaborated questionnaire with the aid of local translators.

Data on socio-demographic characteristics, yam genetic diversity and management, crop husbandry and seedyam production system, and crop utilization. Socio-demographic characteristics includes information on age, gender, educational status, family size, farming experience in years, primary occupation, and farm size. Yam genetic resources includes information on number of landrace varieties, farmer preference criteria, and the diversity management. Crop husbandry and seed yam production system include information on cultivation practices, production and conservation constraints, harvesting, and seed tuber farming.

\subsection{Statistical analysis}

Descriptive statistics (frequencies, means, minimum, maximum, etc.) was used in generating summary tables. Pearson's correlation was used to assess the relationship among the socio-demographic characteristics and the yam diversity maintained at the household level using corrplot library R package [25]. Shannon-Weiner diversity index $\left(\mathrm{H}^{\prime}\right)$, species richness and equitability $(\mathrm{E})$ were used to quantify the diversity of yam at the village, territory and province levels. Subject to synonymy / homonymy, a data base was constructed by considering the unique landrace morphotypes based on different villages and the farmers' identified agronomic and tuber quality traits. These traits include; tuber flesh oxidation status after cooking rated 1 to 3 ( $1=$ no change in colour; $2=$ slightly darken after cooking; $3=$ heavily darken after cooking), tuber taste rated 1 to 3 ( $1=$ sweet; $2=$ intermediate; $3=$ bitter), tuber flesh colour rated 1 to 9 ( 1 = white; $2=$ cream-white; $3=$ yellow; $4=$ purple; $5=$ purplish-white; $6=$ creamy; $7=$ brownish-white; $8=$ deep purple; $9=$ orange), tuber shape rated 1 to 5 ( $1=$ oval; $2=$ spherical; $3=$ cylindrical; $4=$ oblong; $5=$ irregular $)$ and maturity duration rated 1 to 3 ( $1=$ early "less than 8 months"; $2=$ intermediate "8-10 months"; $3=$ late "greater than 10 months") This data base was used in cluster analysis to construct a dendrogram to compare the relatedness among the unique landrace varieties using the cluster package in $\mathrm{R}[26]$.

\subsection{Results}

\subsection{Sociodemographic characteristics of the study areas}

Among the 540 farmers, $80.60 \%$ were male while $19.40 \%$ were female with an average of 13 years of experience in Dioscorea species production. Besides, $1.30 \%$ of the farmers surveyed were teenagers (< 20 years), $73.30 \%$ were adults class (20-50 years) and $25.40 \%$ were old people (> 50 years). Secondary and primary educations ( $59.80 \%$ and $34.60 \%$ respectively) were the most common form of education. The major activity of the farmers is farming 
(98.70\%). The average family size of the survey participants was approximately 7 members with a minimum of one member and a maximum of 24 members in the case of extended family. The average farm size was 1.49 hectare with a recorded minimum farm size of 0.10 hectare and maximum farm size of 15 hectares. The average size of yam field under cultivation was 0.10 hectare with a maximum of 1.50 hectares. With respect to yam cultivation relative to other crops (food and cash), yam took an approximate of $7 \%$ of the total available land for crop cultivation in general (Table 2).

Table 2: Sociodemographic analysis of the survey territories 
Territory

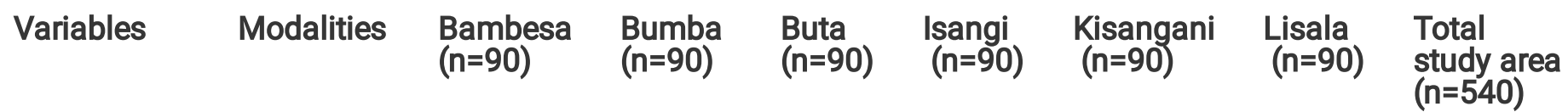

\begin{tabular}{|lllllllll|}
\hline Gender (\%) & Male & 83.30 & 93.30 & 94.40 & 66.70 & 76.70 & 96.70 & 80.60 \\
\hline & Female & 16.70 & 6.70 & 5.60 & 33.30 & 23.30 & 3.30 & 19.40 \\
\hline $\begin{array}{l}\text { Education } \\
\text { level (\%) }\end{array}$ & $\begin{array}{l}\text { No formal } \\
\text { education }\end{array}$ & 3.30 & 6.70 & 2.20 & 2.20 & 8.90 & 2.20 & 4.30 \\
\hline & Primary & 44.40 & 34.40 & 50.00 & 27.80 & 24.40 & 26.70 & 34.60 \\
\hline & Secondary & 52.20 & 57.80 & 46.60 & 70.00 & 63.30 & 68.90 & 59.80 \\
\hline & Tertiary & - & 1.10 & 1.10 & - & 3.30 & 2.20 & 1.30 \\
\hline $\begin{array}{l}\text { Major } \\
\text { cccupation } \\
\text { (\%) }\end{array}$ & Farming & 97.80 & 96.70 & 100.00 & 98.90 & 100.00 & 98.90 & 98.70 \\
\hline
\end{tabular}

\begin{tabular}{|c|c|c|c|c|c|c|c|c|}
\hline & $\begin{array}{l}\text { Non- } \\
\text { farming }\end{array}$ & 2.20 & 3.30 & - & 1.10 & - & 1.10 & 1.30 \\
\hline \multirow[t]{5}{*}{$\begin{array}{l}\text { Age range } \\
\text { (year) }\end{array}$} & $\begin{array}{l}\text { Less than } \\
20\end{array}$ & 2.20 & 1.10 & - & 1.10 & - & 3.30 & 1.30 \\
\hline & 20 to 30 & 27.80 & 17.80 & 26.70 & 31.10 & 22.20 & 22.20 & 24.60 \\
\hline & 31 to 40 & 26.70 & 33.30 & 31.10 & 21.10 & 32.20 & 27.80 & 28.70 \\
\hline & 41 to 50 & 18.90 & 27.80 & 18.90 & 15.60 & 11.10 & 27.80 & 20.00 \\
\hline & $\begin{array}{l}\text { Greater } \\
\text { than } 50\end{array}$ & 24.40 & 20.00 & 23.30 & 31.50 & 34.40 & 18.90 & 25.40 \\
\hline \multirow[t]{3}{*}{ Family size } & Average & 6.86 & 8.14 & 7.40 & 7.21 & 7.34 & 8.47 & 7.60 \\
\hline & Minimum & 1.00 & 1.00 & 1.00 & 1.00 & 2.00 & 3.00 & 1.00 \\
\hline & Maximum & 22.00 & 21.00 & 19.00 & 24.00 & 18.00 & 19.00 & 24.00 \\
\hline \multirow[t]{3}{*}{$\begin{array}{l}\text { Respondent } \\
\text { position }\end{array}$} & $\begin{array}{l}\text { Family } \\
\text { head }\end{array}$ & 82.20 & 94.40 & 73.30 & 73.30 & 76.70 & 96.70 & 82.80 \\
\hline & $\begin{array}{l}\text { Family } \\
\text { member }\end{array}$ & 17.80 & 5.60 & 26.70 & 26.70 & 23.30 & 3.30 & 17.20 \\
\hline & $\begin{array}{l}\text { Distant } \\
\text { member }\end{array}$ & - & - & - & - & - & & - \\
\hline \multirow{3}{*}{$\begin{array}{l}\text { Yam field } \\
\text { size (ha) }\end{array}$} & Average & 0.01 & 0.41 & 0.03 & 0.05 & 0.07 & 0.03 & 0.10 \\
\hline & Minimum & 0.002 & 0.000 & 0.001 & 0.010 & 0.010 & 0.001 & 0.000 \\
\hline & Maximum & 0.20 & 1.50 & 1.00 & 0.50 & 1.00 & 0.50 & 1.50 \\
\hline \multirow{2}{*}{$\begin{array}{l}\text { Farm size } \\
\text { (ha) }\end{array}$} & Average & 0.98 & 2.65 & 1.33 & 1.31 & 1.27 & 1.40 & 1.49 \\
\hline & Minimum & 0.10 & 0.50 & 0.50 & 0.40 & 0.25 & 0.50 & 0.10 \\
\hline
\end{tabular}




\begin{tabular}{lllllllll} 
& Maximum & 2.50 & 11.00 & 4.00 & 10.00 & 12.00 & 15.00 & 15.00 \\
\hline $\begin{array}{l}\text { Land use } \\
\begin{array}{l}\text { (\%) } \\
\text { Yam }\end{array}\end{array}$ & 1.44 & 15.86 & 1.98 & 3.65 & 5.35 & 2.03 & 6.62 \\
\hline & $\begin{array}{l}\text { Other } \\
\text { crops }\end{array}$ & 98.56 & 84.14 & 98.02 & 96.35 & 94.65 & 97.97 & 93.38 \\
\hline $\begin{array}{l}\text { Yam } \\
\text { experience } \\
\text { (year) }\end{array}$ & Average & 10.81 & 8.57 & 11.48 & 15.84 & 14.09 & 13.89 & 12.46 \\
\hline & Minimum & 1.00 & 1.00 & 1.00 & 1.00 & 1.00 & 1.00 & 1.00 \\
\hline & Maximum & 50.00 & 35.00 & 45.00 & 63.00 & 43.00 & 47.00 & 63.00 \\
\hline
\end{tabular}

\subsection{Constraints to yam production in DR Congo}

Generally, tuber quality forms the highest proportion (69\%) of the farmers' constraints to yam production. The traits reported by farmers under the tuber quality were poor postharvest shelf life $(30.58 \%)$, high tuber flesh oxidation (14.54\%), poor taste $(\sim 14 \%)$ and rapid hardiness of tubers $(10 \%)$. The tuber quality traits were reported by farmers at all the territories (Table 3 ).

The biotic factors (9.56\%) followed after tuber quality. This category of constraint was largely influenced by the proportion of farmers who reported harvest pests' problem ( $7 \%)$ while theft was only $\sim 3 \%$. The abiotic factors form the third constraint reported by farmers $(8.96 \%)$. This constraint was influenced by farmers who reported poor soil $(6 \%)$ compared to other factors in this category. Poor soil was reported by farmers in four of the six territories.

Agronomic quality $(7.26 \%)$ was also identified by farmers as a constraint to production. Similar to abiotic factors, the agronomic quality was also influenced by difficulty in harvesting (6\%) compare to other factors in similar category. Difficulty in harvesting was also reported in four of the six territories. The last production constraint reported by farmers was marketing $(\sim 5 \%)$. This constraint category forms the least of the farmers' production constraints. It is also influenced by the proportion of farmers who reported poor market price for yam tubers ( $4 \%)$. In summary, the major factors reported by farmers as constraints to yam production in DR Congo are: poor post-harvest shelf life, high tuber flesh oxidation, poor tuber taste, rapid tuber hardiness, pests, difficulty in harvesting, poor soil, and poor market price.

Different territories have different constraints affecting yam production. For example, while tuber quality traits were identified as the primary production constraints for Bambesa (94\%), Buta ( 62\%), Lisala (85\%), Kisangani $(\sim 62 \%)$ and Isangi ( 92\%), it was not the case for Bumba (21\%) rather biotic factors $(40 \%)$ forms the primary constraints to production in this territory. Yams in this territory were not affected by poor taste and tuber hardiness (Table 3).

\section{Table 3: Summary of constraints limiting yam production in DR Congo}




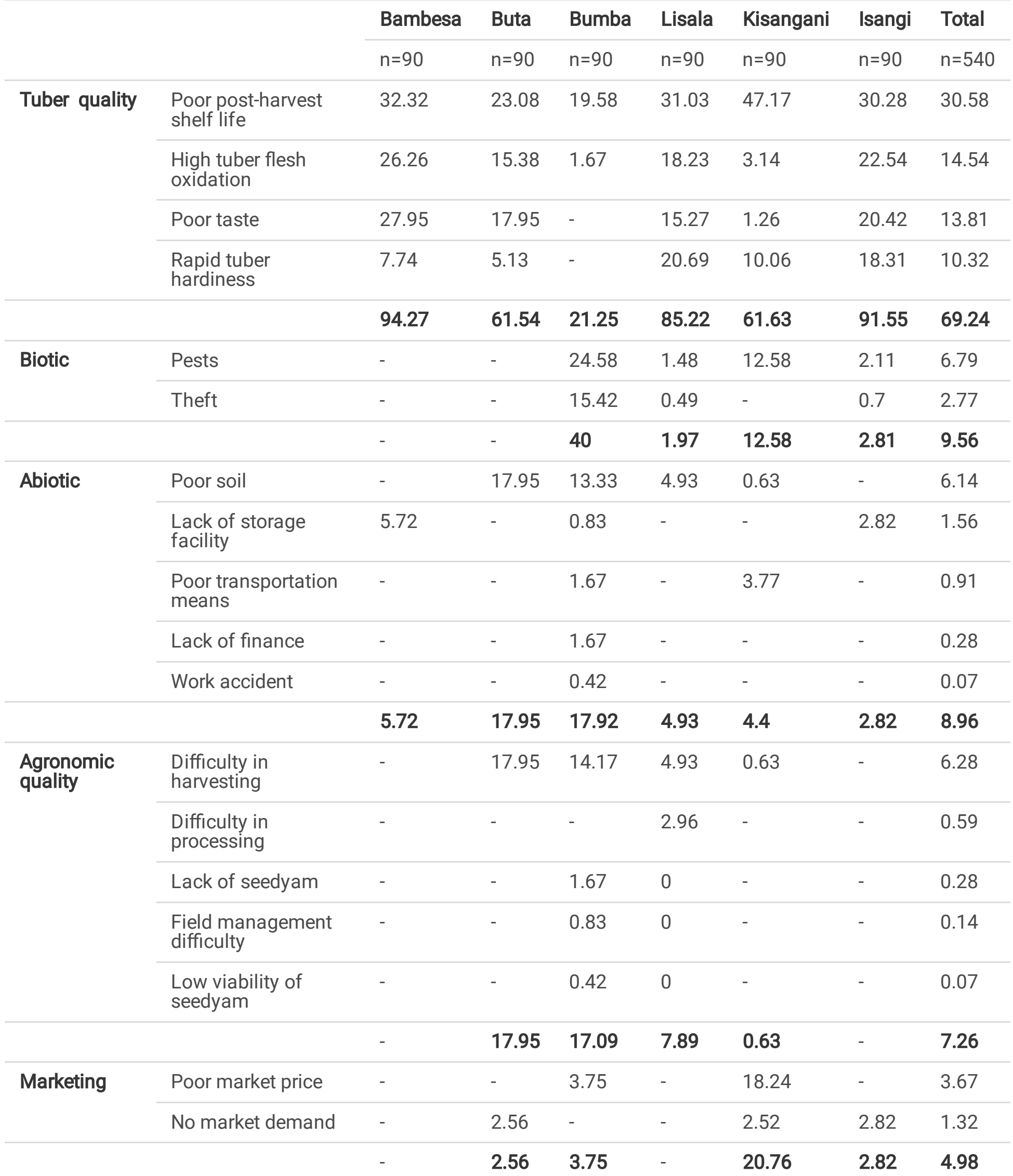




\subsection{Yam genetic Diversity}

The diversity of yam (cultivated and naturally existing in the forest) in DR Congo is presented in Table 4. Considering the possibility of synonyms, the numbers of yam landrace genotypes recorded ranged from two to ten per village. The minimum number of landrace (2) was observed in the villages of Bambesa (Adiwaya, Bongenge, Dingima, and Mendigba) and Buta (Bobomale, Bonzo and Boyelia) territories while the maximum number of landrace genotypes (10) was observed in the villages of Isangi territory (Q. Bangala and Q. Lumumba).

The mean diversity index expressed as Shannon index $\left(\mathrm{H}^{\prime}\right)$ and the $\mathrm{H}$ max (the possible maximum diversity that could exist as at the time of the survey) across the villages were 1.32 and 1.58 respectively. With these information, the mean equitability (E) was 0.84 . On the basis of territory, Kisangani city had the highest recorded $H^{\prime}$ and $H_{-}$max of 2.60 and 3.04. On the other hand, Buta recorded the lowest landrace richness, $H^{\prime}$, H_max and E values $(7,1.39,1.95$ and 0.71 respectively). Nevertheless, that Kisangani city had the highest landrace richness and $\mathrm{H}^{\prime}$, Bumba recorded the highest value for $E(0.89)$. At the province level, Tshopo province had the highest landrace richness, $H^{\prime}$ and $H_{-}$max values of 35, 2.79 and 3.56 respectively while Mongala province top the E column with a value of 0.85 . Bas-Uélé came last in all ramifications (landrace richness=10; $H^{\prime}=1.67 ; H \_m a x=2.30 ; E=0.73$ ) (Table 4).

The relationship between socio-demographic characteristics and the number of landrace genotypes cultivated at individual household level is presented in Figure 2. Yam experience in yam cultivation, family size, total farm size, major occupation, and age range had positive impact with number of landrace genotypes cultivated at household level.

Throughout the entire survey period, five different species of yams (Dioscorea rotundata, Dioscorea cayenensis, Dioscorea alata, Dioscorea dumetorum and Dioscorea bulbifera) were recorded. These form the major landrace genotypes that were cultivated by farmers as well as naturally existing in the forest in the survey areas (Table 5). The quantity of landrace varieties per species also varies significantly from one village to another with number varying from one to three (Dioscorea rotundata, Dioscorea cayenensis, and Dioscorea dumetorum), one to four (Dioscorea alata), and one to two (Dioscorea bulbifera). Only two villages: Quartier Bangala and Yalinga in Isangi territory (Tshopo province) were found to have all the yam species represented.

The maturity classification of the yams in DR Congo was also assessed (Table 6). $74 \%$ of the farmers reported that the yams are of the late maturity class (>10 months), 17\% reported intermediate maturity class (8 - 10 months) and $9 \%$ reported early maturity class (< 8months). At the territory level, majority of the farmers also agreed to the yams being the late maturity class except for farmers in the Kisangani territory. In this territory, $33 \%$ of the farmers reported early maturity class, $36 \%$ reported intermediate maturity class and $31 \%$ reported late maturity class.

The relationship among the unique 67 yam landraces observed during the survey period with respect to agronomic characters (tuber shape and maturity duration), tuber quality parameters (tuber colour, tuber taste, and tuber oxidation (browning) after cooking) and yam species is represented in Figure 4. The cluster analysis partitioned the different landrace varieties of yams into four clusters. Cluster one consists of landrace varieties of the $D$. rotundata and D. alata having irregular tuber shape, creamy flesh colour, intermediate to late maturity, sweet taste, and nooxidation to slight browningafter cooking. Cluster two consists of landrace varieities of the $D$. rotundata, D. alata and $D$. dumetorum having oval and spherical tuber shape, white and purplish-white flesh colour, early to late maturity, intermediate to bitter taste, and no-oxidation to heavy browning after cooking. Cluster three consists of landrace varieties of the $D$. rotundata, $D$. alata and $D$. cayenensis having cylindrical and oblong tuber shape, white flesh colour, early to late maturity, sweet to intermediate taste and no-oxidation to heavy browningafter cooking. Cluster four 
comprised of landrace varieties of the $D$. cayenensis, $D$. alata, $D$. dumetorum having cylindrical and oblong tuber shape, white, yellow and purple colour, early to late maturity, sweet to bitter taste, and no-oxidation to heavy browning after cooking.

Following the observed diversity of yams in the study areas, approximately $74 \%$ of the farmers also reported landraces experiencing decline in attention by farmers or extinction (Table 7). A total of 14 yam landrace names were reported by farmers that fall in this category of event. Of the proportion of farmers that reported varietal loss, $78 \%$ reported poisons as the principal reason for extinction, $10 \%$ and $8 \%$ reported poor tuber quality and late maturity as the cause for extinction respectively. At the territory level, farmers in Bambesa and Buta territories reported that the landraces contain poisonous substance. Farmers in Kisangani and Isangi territories reported late maturity (44\% and $\sim 6 \%$ respectively) in addition to being poisonous as primary reason ( $56 \%$ and $94 \%$ respectively). In Lisala territory, farmers reported poor tuber quality (4\%) in addition to being poisonous as primary reason (96\%). Farmers in the Bumba territory however had different principal reasons. Approximately $54 \%$ of the farmers reported poor tuber quality as the primary reason. Other reasons reported in this territory are poison (24\%), lack of market demand (17\%), low shelf life (11\%) and poor yield (5\%).

Table 4: Genetic diversity of Yams across province, Territory and Village in the surveyed area 


\begin{tabular}{|c|c|c|c|c|c|}
\hline & Adiwaya & 2 & 0.30 & 0.69 & 0.44 \\
\hline & Bango & 3 & 0.89 & 1.10 & 0.81 \\
\hline & Bombele & 3 & 0.89 & 1.10 & 0.81 \\
\hline & Bongenge & 2 & 0.60 & 0.69 & 0.86 \\
\hline & Bulusu & 4 & 1.12 & 1.39 & 0.81 \\
\hline & Dingima & 2 & 0.45 & 0.69 & 0.65 \\
\hline & Mendigba & 2 & 0.66 & 0.69 & 0.95 \\
\hline & Mupembe & 4 & 1.09 & 1.39 & 0.79 \\
\hline & Ngbonga & 4 & 1.28 & 1.39 & 0.92 \\
\hline \multirow[t]{10}{*}{ Bambesa } & & 7 & 1.45 & 1.95 & 0.75 \\
\hline & Baebona & 5 & 1.48 & 1.61 & 0.92 \\
\hline & Bobanabendea & 5 & 1.31 & 1.61 & 0.82 \\
\hline & Bobomale & 2 & 0.64 & 0.69 & 0.92 \\
\hline & Bonzo & 2 & 0.54 & 0.69 & 0.78 \\
\hline & Boyelia & 2 & 0.64 & 0.69 & 0.92 \\
\hline & Kumu & 3 & 0.88 & 1.10 & 0.80 \\
\hline & Monjila & 3 & 0.85 & 1.10 & 0.77 \\
\hline & Q.Bale & 4 & 1.11 & 1.39 & 0.80 \\
\hline & Sombo & 3 & 0.82 & 1.10 & 0.75 \\
\hline Buta & & 7 & 1.39 & 1.95 & 0.71 \\
\hline \multirow[t]{10}{*}{ Bas-Uélé } & & 10 & 1.67 & 2.30 & 0.73 \\
\hline & Bongolo-II & 4 & 1.12 & 1.39 & 0.81 \\
\hline & Bonzo & 7 & 1.82 & 1.95 & 0.93 \\
\hline & Botsholi-I & 3 & 1.08 & 1.10 & 0.98 \\
\hline & Botsholi-II & 3 & 0.60 & 1.10 & 0.55 \\
\hline & Yamaluka-II & 3 & 0.92 & 1.10 & 0.83 \\
\hline & Yamoguo & 4 & 1.35 & 1.39 & 0.98 \\
\hline & Yamolea-I & 4 & 1.12 & 1.39 & 0.80 \\
\hline & Yanjumbu & 5 & 1.30 & 1.61 & 0.81 \\
\hline & Yapembe & 4 & 1.12 & 1.39 & 0.81 \\
\hline
\end{tabular}




\begin{tabular}{|c|c|c|c|c|c|}
\hline \multicolumn{2}{|l|}{ Bumba } & 15 & 2.42 & 2.71 & 0.89 \\
\hline & Bobi & 6 & 1.66 & 1.79 & 0.92 \\
\hline & Bokutu & 7 & 1.67 & 1.95 & 0.86 \\
\hline & Bosokuluki-I & 3 & 1.00 & 1.10 & 0.91 \\
\hline & Bosokuluki-II & 4 & 1.09 & 1.39 & 0.79 \\
\hline & Botukwa & 6 & 1.40 & 1.79 & 0.78 \\
\hline & Dika & 9 & 2.00 & 2.20 & 0.91 \\
\hline & Liweya & 6 & 1.52 & 1.79 & 0.85 \\
\hline & Mapasa & 5 & 1.47 & 1.61 & 0.92 \\
\hline & Ngunzibalele & 5 & 1.47 & 1.61 & 0.91 \\
\hline Lisala & & 16 & 2.22 & 2.77 & 0.80 \\
\hline Mongala & & 26 & 2.77 & 3.26 & 0.85 \\
\hline & Lilanda & 4 & 1.08 & 1.39 & 0.78 \\
\hline & Q. Bangala & 10 & 2.20 & 2.30 & 0.96 \\
\hline & Q. Lumumba & 10 & 1.91 & 2.30 & 0.83 \\
\hline & Yakako-I & 3 & 1.06 & 1.10 & 0.96 \\
\hline & Yakpondi & 4 & 1.27 & 1.39 & 0.91 \\
\hline & Yalibua & 4 & 1.35 & 1.39 & 0.97 \\
\hline & Yalinga & 8 & 1.80 & 2.08 & 0.87 \\
\hline & Yaondolo-II & 4 & 1.33 & 1.39 & 0.96 \\
\hline & Yaselia & 4 & 1.23 & 1.39 & 0.89 \\
\hline Isangi & & 20 & 2.32 & 3.00 & 0.78 \\
\hline & Babugana & 5 & 1.33 & 1.61 & 0.82 \\
\hline & Batikayafi & 4 & 1.07 & 1.39 & 0.77 \\
\hline & Likenga & 3 & 0.60 & 1.10 & 0.55 \\
\hline & Lugnunga & 6 & 1.58 & 1.79 & 0.88 \\
\hline & Magbololo & 4 & 0.98 & 1.39 & 0.71 \\
\hline & Maleke & 7 & 1.53 & 1.95 & 0.79 \\
\hline & Ngenengene & 4 & 1.21 & 1.39 & 0.87 \\
\hline & Ngenengene-II & 4 & 1.32 & 1.39 & 0.95 \\
\hline & Osio & 5 & 1.38 & 1.61 & 0.86 \\
\hline Kisangani city & & 21 & 2.60 & 3.04 & 0.85 \\
\hline Tshopo & & $\begin{array}{l}35 \\
\text { Page }\end{array}$ & 2.79 & 3.56 & 0.79 \\
\hline
\end{tabular}


Table 5: Yam species diversity across the study area 


\begin{tabular}{|c|c|c|c|c|c|c|c|c|c|}
\hline Province & Territory & Village & $E$ & D. rot & D. ala & D. cay & D. bul & D. dum & Total \\
\hline \multirow[t]{18}{*}{ Bas-Uélé } & \multirow[t]{9}{*}{ Bambesa } & Adiwaya & 0.44 & 1 & & 1 & & & 2 \\
\hline & & Bango & 0.81 & 2 & & 1 & & & 3 \\
\hline & & Bombele & 0.81 & 2 & & 1 & & & 3 \\
\hline & & Bongenge & 0.86 & 1 & & 1 & & & 2 \\
\hline & & Bulusu & 0.81 & 3 & & 1 & & & 4 \\
\hline & & Dingima & 0.65 & 1 & & 1 & & & 2 \\
\hline & & Mendigba & 0.95 & 1 & & 1 & & & 2 \\
\hline & & Mupembe & 0.79 & 3 & & 1 & & & 4 \\
\hline & & Ngbonga & 0.92 & 2 & 1 & 1 & & & 4 \\
\hline & \multirow[t]{9}{*}{ Buta } & Baebona & 0.92 & 2 & 1 & 1 & & 1 & 5 \\
\hline & & Bobanabendea & 0.82 & 2 & 1 & 1 & & 1 & 5 \\
\hline & & Bobomale & 0.92 & 1 & & 1 & & & 2 \\
\hline & & Bonzo & 0.78 & 1 & & 1 & & & 2 \\
\hline & & Boyelia & 0.92 & 1 & & 1 & & & 2 \\
\hline & & Kumu & 0.80 & 1 & 1 & 1 & & & 3 \\
\hline & & Monjila & 0.77 & 1 & 1 & 1 & & & 3 \\
\hline & & Q.Bale & 0.80 & 2 & & 1 & & 1 & 4 \\
\hline & & Sombo & 0.75 & 1 & 1 & 1 & & & 3 \\
\hline \multirow[t]{13}{*}{ Mongala } & \multirow[t]{9}{*}{ Bumba } & Bongolo-II & 0.81 & & 2 & 1 & & 1 & 4 \\
\hline & & Bonzo & 0.93 & 1 & 2 & 3 & & 1 & 7 \\
\hline & & Botsholi-I & 0.98 & & 1 & 1 & & 1 & 3 \\
\hline & & Botsholi-II & 0.55 & & 2 & 1 & & & 3 \\
\hline & & Yamaluka-II & 0.83 & & & 3 & & & 3 \\
\hline & & Yamoguo & 0.98 & & 1 & 3 & & & 4 \\
\hline & & Yamolea-II & 0.80 & & 1 & 3 & & & 4 \\
\hline & & Yanjumbu & 0.81 & & 3 & 1 & & 1 & 5 \\
\hline & & Yapembe & 0.81 & 1 & & 3 & & & 4 \\
\hline & \multirow[t]{4}{*}{ Lisala } & Bobi & 0.92 & 1 & 2 & 2 & & 1 & 6 \\
\hline & & Bokutu & 0.86 & 2 & 2 & 2 & & 1 & 7 \\
\hline & & Bosokuluki-I & 0.91 & & 2 & 1 & & & 3 \\
\hline & & Bosokuluki-II & 0.79 & 1 & 1 & 2 & & & 4 \\
\hline
\end{tabular}




\begin{tabular}{|c|c|c|c|c|c|c|c|c|c|}
\hline & & Botukwa & 0.78 & 1 & 2 & 2 & & 1 & 6 \\
\hline & & Dika & 0.91 & 3 & 3 & 1 & & 2 & 9 \\
\hline & & Liweya & 0.85 & 1 & 2 & 2 & & 1 & 6 \\
\hline & & Mapasa & 0.92 & 2 & 2 & 1 & & & 5 \\
\hline & & Ngunzibalele & 0.91 & 2 & 2 & 1 & & & 5 \\
\hline Tshopo & Isangi & Lilanda & 0.78 & & 1 & 1 & & 2 & 4 \\
\hline & & Q. Bangala & 0.96 & 1 & 4 & 1 & 2 & 2 & 10 \\
\hline & & Q. Lumumba & 0.83 & 1 & 3 & 3 & & 3 & 10 \\
\hline & & Yakako-I & 0.96 & & & 1 & & 2 & 3 \\
\hline & & Yakpondi & 0.91 & 1 & & 1 & & 2 & 4 \\
\hline & & Yalibua & 0.97 & & 1 & 1 & & 2 & 4 \\
\hline & & Yalinga & 0.87 & 2 & 2 & 1 & 1 & 2 & 8 \\
\hline & & Yaondolo-II & 0.96 & & 1 & 1 & & 2 & 4 \\
\hline & & Yaselia & 0.89 & 1 & & 1 & & 2 & 4 \\
\hline & Kisangani & Babugana & 0.82 & 1 & 1 & 1 & & 2 & 5 \\
\hline & & Batikayafi & 0.77 & 1 & 1 & 1 & & 1 & 4 \\
\hline & & Likenga & 0.55 & 1 & 1 & 1 & & & 3 \\
\hline & & Lugnunga & 0.88 & 2 & 2 & 1 & & 1 & 6 \\
\hline & & Magbololo & 0.71 & & 1 & 1 & & 2 & 4 \\
\hline & & Maleke & 0.79 & 1 & 3 & 2 & & 1 & 7 \\
\hline & & Ngenengene & 0.87 & 1 & & 2 & 1 & 1 & 5 \\
\hline & & Ngenengene-II & 0.95 & 1 & 1 & 1 & & 1 & 4 \\
\hline & & Osio & 0.86 & 2 & & 1 & & 2 & 5 \\
\hline
\end{tabular}

Table 6: Yam maturity classification 
Category

Bas-Uélé province

Mongala province

Tshopo province

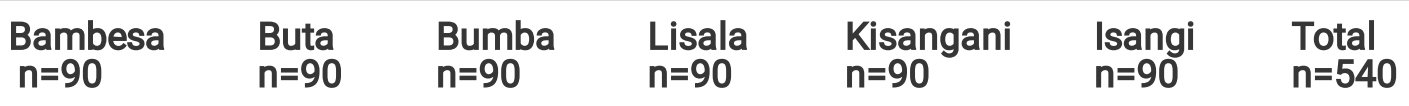

Average yam maturity

level (\%)

\begin{tabular}{llllllll} 
Early $(<8$ months $)$ & - & 7.78 & - & 6.67 & 33.33 & 8.89 & 9.48 \\
\hline $\begin{array}{l}\text { Intermediate (8 to } 10 \\
\text { months) }\end{array}$ & 3.33 & 18.89 & 10.23 & 17.78 & 35.56 & 15.56 & 16.89 \\
\hline Late $(>10$ months) & 96.67 & 73.33 & 89.77 & 75.55 & 31.11 & 75.56 & 73.67
\end{tabular}

Table 7: Reason leading to yam landraces loss

\begin{tabular}{|c|c|c|c|c|c|c|c|}
\hline \multirow[t]{2}{*}{ Category } & \multicolumn{2}{|c|}{ Bas-Uélé province } & \multicolumn{2}{|c|}{ Mongala province } & \multicolumn{2}{|c|}{ Tshopo province } & \multirow[b]{2}{*}{$\begin{array}{l}\text { Total } \\
n=540\end{array}$} \\
\hline & $\begin{array}{l}\text { Bambesa } \\
\mathrm{n}=90\end{array}$ & $\begin{array}{l}\text { Buta } \\
\mathrm{n}=90\end{array}$ & $\begin{array}{l}\text { Bumba } \\
\mathrm{n}=90\end{array}$ & $\begin{array}{l}\text { Lisala } \\
\mathrm{n}=90\end{array}$ & $\begin{array}{l}\text { Kisangani } \\
\mathrm{n}=90\end{array}$ & $\begin{array}{l}\text { Isangi } \\
\mathrm{n}=90\end{array}$ & \\
\hline \multicolumn{8}{|l|}{ Variety in extinction (\%) } \\
\hline Positive response & 100 & 100 & 71.59 & 100 & 10 & 60 & 73.6 \\
\hline $\begin{array}{l}\text { Negative response and } \\
\text { Don't know }\end{array}$ & & & 28.41 & & 90 & 40 & 26.4 \\
\hline Reason for extinction (\%) & & & $\mathrm{n}=65$ & & $\mathrm{n}=9$ & $n=55$ & \\
\hline Poisonous & 100 & 100 & 23.81 & 95.56 & 55.56 & 94.44 & 78.23 \\
\hline Poor tuber quality & - & - & 53.97 & 4.44 & - & - & 9.73 \\
\hline Late maturity & - & - & - & - & 44.44 & 5.56 & 8.33 \\
\hline Lack market demand & - & - & 17.46 & - & - & - & 2.91 \\
\hline Low yield & - & - & 4.76 & - & - & - & 0.79 \\
\hline
\end{tabular}

\subsection{Yam cultivation and cultural practices}

The reason why farmers cultivate yams in DR Congo presented in Table 8 showed that achieving food security (60\%) is of paramount importance to the people than any other factor. Following food security is the generation of income ( 40\%). Similar trends of results were observed at the level of the provinces and the territories.

Cropping system mostly observed in DR Congo was intercropping pattern (90\%) where yam is mostly intercropped with other arable crops. Approximately $10 \%$ of the farmers practice sole cropping system (Table 9 ). At the province and territory level, similar trend of results was obtained except for Bumba territory where the gap between these two cropping systems was significantly reduced. In this territory, over $40 \%$ of the farmers practice sole cropping system for yams as compared to other territories where less than $15 \%$ of the farmers were observed. 
During the production period of yam (Table 9), approximately $58 \%$ of the farmers provide staking support for their yams. At the level of the province, only $18 \%$ responded positively to supporting their yams with stakes during the production cycle in Bas-Uélé. Provinces of Mongala and Tshopo however have appreciable proportion (above 70\%) of farmers that incorporated staking as part of their cultural practice. At the level of the territory, Bambesa had only $\sim 26 \%$ of farmers who practiced staking, Buta had even lesser proportion (11\%) of farmers. While the majority of the farmers in these territories have neglected staking, farmers in the territory Bumba have made it a necessary requirement for yam production. Farmers who practiced staking as part of their regular cultural practice begin one month after planting, with the common staking method being individual plant using the wooden stick cut from the forest (Table 9).

Throughout the survey, the harvest signature used by farmers is total senescence of leaves. Harvesting is only done once as farmers do not practice milking. Once harvesting of the tubers is completed, approximately $89 \%$ of the farmers prefer to go for storage of their produces while $11 \%$ of the farmers send their produce directly to the market for sale. In all the provinces and territories, at least $11 \%$ of the farmers send their produces directly from the field to the market after harvest except for the famers in the province Bas-Uélé (Bambesa and Buta territories) that prefer to go for storage (Table 9).

Table 8: Major reasons why farmers cultivate yams

\begin{tabular}{llllll} 
Province & Territory & Food security (\%) & Medicine (\%) & Social value (\%) & Incomes (\%) \\
\hline & Bambesa & 70.87 & - & - & 29.13 \\
\hline \multirow{2}{*}{ Bas-Uélé } & & 63.83 & - & - & 36.17 \\
\cline { 3 - 3 } & Bumba & 52.49 & - & - & 32.84 \\
\hline \multirow{2}{*}{ Mongala } & & 57.33 & 0.01 & 0.02 & 47.49 \\
\hline & Lisala & 54.88 & - & - & 42.67 \\
\hline & Isangi & 57.69 & 0.01 & 0.01 & 45.10 \\
\hline \multirow{2}{*}{ Tshopo } & Kisangani city & 60.81 & - & - & 42.31 \\
\hline & Total & $\mathbf{5 9 . 2 1}$ & - & - & 39.19 \\
\hline
\end{tabular}

Table 9: Cultural practices in yam farming 
Category

Bas-Uélé province

Mongala province

Tshopo province

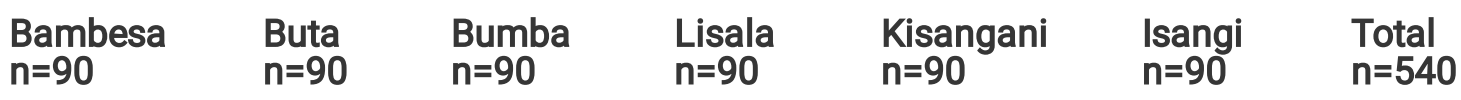

Cropping system

(\%)

$\begin{array}{llllllll}\text { Intercropping } & 100 & 100 & 56.67 & 100 & 88.89 & 95.56 & 90.18 \\ \text { Sole cropping } & - & - & 43.33 & - & 11.11 & 4.44 & 9.82\end{array}$

\section{Staking (\%)}

\begin{tabular}{|c|c|c|c|c|c|c|c|}
\hline Positive response & 25.56 & 11.11 & 100 & 61.11 & 74.44 & 75.56 & 57.96 \\
\hline Negative response & 74.44 & 88.89 & & 38.89 & 25.56 & 24.44 & 42.04 \\
\hline Staking period (\%) & $n=23$ & $n=10$ & $n=90$ & $n=55$ & $\mathrm{n}=67$ & $\mathrm{n}=68$ & $\mathrm{n}=313$ \\
\hline After 1 month & 100 & 100 & 94.44 & 100 & 100 & 100 & 99.07 \\
\hline After 2 months & - & - & - & - & - & - & - \\
\hline After 3 months & - & - & 5.56 & - & - & - & 0.93 \\
\hline After 4 months & - & - & - & - & - & - & - \\
\hline Staking type (\%) & $n=23$ & $n=10$ & $\mathrm{n}=90$ & $\mathrm{n}=55$ & $n=67$ & $n=68$ & $n=313$ \\
\hline Trellis & - & - & - & - & - & - & - \\
\hline Individual & 100 & 100 & 100 & 100 & 100 & 100 & 100 \\
\hline Group & - & - & - & - & - & - & - \\
\hline $\begin{array}{l}\text { Staking material } \\
(\%)\end{array}$ & $n=23$ & $n=10$ & $\mathrm{n}=90$ & $\mathrm{n}=55$ & $n=67$ & $n=68$ & $n=313$ \\
\hline Wooden stick & 100 & 100 & 100 & 100 & 100 & 100 & 100 \\
\hline Bamboo stick & - & - & - & - & - & - & - \\
\hline Others & - & - & - & - & - & - & - \\
\hline $\begin{array}{l}\text { Harvest signature } \\
(\%)\end{array}$ & - & - & - & - & - & - & - \\
\hline $\begin{array}{l}\leq 25 \% \text { leaf } \\
\text { senescence }\end{array}$ & - & - & - & - & - & - & - \\
\hline $\begin{array}{l}50 \% \text { leaf } \\
\text { senescence }\end{array}$ & - & - & - & - & - & - & - \\
\hline $\begin{array}{l}100 \% \text { leaf } \\
\text { senescence }\end{array}$ & 100 & 100 & 100 & 100 & 100 & 100 & 100 \\
\hline \multicolumn{8}{|l|}{$\begin{array}{l}\text { Number of harvest } \\
(\%)\end{array}$} \\
\hline Once & 100 & 100 & 100 & 100 & 100 & 100 & 100 \\
\hline Twice & - & - & - & - & - & - & - \\
\hline
\end{tabular}




\section{Activity after}

harvest (\%)

\begin{tabular}{llllllll} 
Storage & 100 & 100 & 75.56 & 88.89 & 85.56 & 82.22 & 88.71 \\
\hline Sold directly & - & - & 24.44 & 11.11 & 14.44 & 17.78 & 11.30
\end{tabular}

\subsection{Seedyam production system}

Of the four different sources of seedyam presented to the farmers, the backyard source (43.26\%) (retention from previous season harvest) and neighbor source (31.37\%) (exchange with neighboring farmers and friends) were the frequently used sources that farmers practice to obtain their seedyam (Table 10). At the level of the province, farmers in the Bas-Uélé province reported forest as a source of seedyam alongside backyard and neighbor sources (backyard $=35.41 \%$; neighbor $=33.15 \%$ and forest $=25.21 \%$ ). Farmers in Mongala province reported the use of three different sources (backyard $=45.90 \%$; market $=27.40 \%$ and neighbor $=26.69 \%$ ) for obtaining seedyam. Farmers in Tshopo province significantly use two sources (backyard $=53 \%$ and neighbor $=35 \%$ ) sources as against three sources practiced by other provinces. The importance of forest as a source of seedyam was only reported in the Bas-Uele province.

At the level of the territory, farmers in Bambesa preferred the use of the forest source (50\%) compared to the backyard (29\%) and neighbor ( 21\%). Farmers in Buta showed preference for neighbor ( 46\%) and backyard ( 42\%) sources. In this territory, the proportion of farmers that depend on market source for obtaining seedyam is very low (12\%). In Bumba, majority of the farmers reported the use backyard source (48\%), 31\% reported market source and $21 \%$ reported neighbor source. In Lisala, the majority of the farmers also have preference for backyard source ( 45\%), 30\% preferred neighbor source and 25\% preferred market source for obtaining their seedyam. Farmers in Isangi territory however reported the practice of two sources (backyard= $\sim 52 \%$ and neighbor= 48\%). In Kisangani, three sources were reported by the farmers. $56 \%$ of the farmers reported backyard source, $23 \%$ reported market source and $\sim 21 \%$ reported neighbor source. Aside from Bambesa territory where farmers reported the use of the forest source as the most preferred seedyam source, majority of the farmers in the other territories prefer the backyard sources as the most preferred source for obtaining seedyam (Table 10).

\section{Table 10: Seedyam sources in the study area}




\begin{tabular}{|c|c|c|c|c|c|c|}
\hline Province & Territory & Village & Market (\%) & Neighbor (\%) & Backyard (\%) & Forest (\%) \\
\hline & & Adiwaya & - & 8.33 & 8.33 & 83.33 \\
\hline & & Bango & - & 9.52 & 42.86 & 47.62 \\
\hline & & Bombele & - & 19.05 & 33.33 & 47.62 \\
\hline & & Bongenge & - & 26.67 & 6.67 & 66.67 \\
\hline & & Bulusu & - & 16.67 & 41.67 & 41.67 \\
\hline & & Dingima & - & - & 44.44 & 55.56 \\
\hline & & Mendigba & - & 43.48 & 21.74 & 34.78 \\
\hline & & Mupembe & - & 9.09 & 45.45 & 45.45 \\
\hline & & Ngbonga & - & 47.37 & - & 52.63 \\
\hline \multirow{10}{*}{\multicolumn{2}{|c|}{ Bambesa }} & & & 20.57 & 29.14 & 50.29 \\
\hline & & Baebona & - & 50.00 & 50.00 & - \\
\hline & & Bobanabendea & 11.11 & 50.00 & 38.89 & - \\
\hline & & Bobomale & 19.05 & 33.33 & 47.62 & - \\
\hline & & Bonzo_But. & 12.50 & 56.25 & 31.25 & - \\
\hline & & Boyelia & 9.52 & 47.62 & 42.86 & - \\
\hline & & Kumu & 15.79 & 47.37 & 31.58 & 5.26 \\
\hline & & Monjila & 19.05 & 42.86 & 38.10 & - \\
\hline & & Q.Bale & 21.74 & 34.78 & 43.48 & - \\
\hline & & Sombo & - & 52.63 & 47.37 & - \\
\hline \multicolumn{3}{|c|}{ Buta } & 12.43 & 45.76 & 41.81 & 0.01 \\
\hline \multirow{10}{*}{\multicolumn{2}{|c|}{ Bas-Uélé }} & & 6.23 & 33.15 & 35.41 & 25.21 \\
\hline & & Bongolo_II & 18.18 & 27.27 & 54.55 & - \\
\hline & & Bonzo_Bum. & 8.33 & 8.33 & 83.33 & - \\
\hline & & Botsholi_I & 8.33 & 41.67 & 50.00 & - \\
\hline & & Botsholi_II & 60.00 & 10.00 & 30.00 & - \\
\hline & & Yamaluka_II & 23.08 & 46.15 & 30.77 & - \\
\hline & & Yamoguo & - & 30.77 & 69.23 & - \\
\hline & & Yamolea_II & 81.82 & - & 18.18 & - \\
\hline & & Yanjumbu & 23.08 & 15.38 & 61.54 & - \\
\hline & & Yapembe & 72.73 & - & 27.27 & - \\
\hline & Bumba & & 31.13 & 20.75 & 48.12 & - \\
\hline
\end{tabular}




\begin{tabular}{|c|c|c|c|c|c|}
\hline & Bobi & 10.00 & 50.00 & 40.00 & - \\
\hline & Bokutu & 10.00 & 50.00 & 40.00 & - \\
\hline & Bosokuluki_I & 36.84 & 15.79 & 47.37 & - \\
\hline & Bosokuluki_Il & 35.00 & 25.00 & 40.00 & - \\
\hline & Botukwa & 47.06 & 5.88 & 47.06 & - \\
\hline & Dika & 28.57 & 28.57 & 42.86 & - \\
\hline & Liweya & 28.57 & 23.81 & 47.62 & - \\
\hline & Mapasa & 5.88 & 35.29 & 52.94 & 5.88 \\
\hline & Ngunzibalele & 22.73 & 31.82 & 40.91 & 4.55 \\
\hline Lisala & & 25.14 & 30.28 & 44.57 & 0.01 \\
\hline Mongala & & 27.40 & 26.69 & 45.90 & 0.01 \\
\hline & Lilanda & - & 41.18 & 58.82 & - \\
\hline & Q. Bangala & 5.26 & 47.37 & 47.37 & - \\
\hline & Q. Lumumba & - & 42.86 & 47.62 & 9.52 \\
\hline & Yakako_I & - & 62.50 & 37.50 & - \\
\hline & Yakpondi & - & 29.41 & 52.94 & 17.65 \\
\hline & Yalibua & 6.25 & 43.75 & 50.00 & - \\
\hline & Yalinga & - & 52.63 & 47.37 & - \\
\hline & Yaondolo_II & - & 45.00 & 45.00 & 10.00 \\
\hline & Yaselia & 5.00 & 45.00 & 50.00 & - \\
\hline Isangi & & 0.02 & 48.35 & 51.59 & 0.05 \\
\hline & Babugana & 25.00 & 8.33 & 66.67 & - \\
\hline & Batikayafi & 14.29 & 21.43 & 57.14 & 7.14 \\
\hline & Likenga & 44.44 & 16.67 & 38.89 & - \\
\hline & Lugnunga & 9.09 & 18.18 & 72.73 & - \\
\hline & Magbololo & - & 40.00 & 60.00 & - \\
\hline & Maleke & 40.91 & 9.09 & 40.91 & 9.09 \\
\hline & Ngenengene & - & 20.00 & 66.67 & 13.33 \\
\hline & Ngenengene_II & 23.81 & 23.81 & 33.33 & 19.05 \\
\hline & Osio & - & 30.00 & 70.00 & - \\
\hline \multicolumn{2}{|c|}{ Kisangani city } & 22.56 & 20.95 & 56.41 & 0.07 \\
\hline \multicolumn{2}{|l|}{ Tshopo } & 10.99 & 35.80 & 53.16 & 0.06 \\
\hline & Total & $\begin{array}{r}13.92 \\
\text { Page }\end{array}$ & 31.37 & 43.26 & 11.46 \\
\hline
\end{tabular}




\subsection{Farmers' preference criteria for yam selection and utilization in DR Congo}

The assessment of farmers' preference criterial for yam selection and utilization in DR Congo is presented in Table 11. The preference for yams variety with good tuber quality (sweet taste and no tuber browning after cooking) was reported by $53 \%$ of the farmers, high yield preference was reported by $38 \%$ of the farmers, and preference for earliness was reported by $7 \%$ of the farmers. Thus, these three criterial accounted for over $97 \%$ of the farmers'

preference in DR Congo. At the level of the province, similar trend of results was observed across the three province however, this was not totally the case at the level of the territory. Farmers in Bambesa territory only reported the preferences for two criteria only (high yield $=50 \%$ and good tuber quality $=50 \%$ ). Farmers in Buta showed preference for three criteria with importance placed on two (good tuber quality $=57 \%$ and high yield $=42 \%$ ). A very insignificant proportion recognized the need for earliness in yam (1\%). Farmers in Bumba reported four criteria with importance placed on two criteria (high yield $=47 \%$ and good tuber quality $=47 \%$ ). Farmers in Lisala reported the preference for all the traits provided however with emphasis on good tuber quality (59\%) and high yield (30\%). Farmers in Kisangani reported the preference for three criteria (good tuber quality $=47 \%$; earliness $=37 \%$; high yield $=16 \%$ ). Farmers in Isangi also reported preference for three traits with emphasis on two (good tuber quality= 56\% and high yield= $42 \%$ ).

The major form of consumption was assessed amongst the survey respondents and presented in Table 11. In general, approximately $76 \%$ of the respondents consume yam in boiled form, $11 \%$ consume yam in pounded form, $8 \%$ consumed yam in grilled form and $5 \%$ consume yam in fried form. Value addition form remain unknown to the survey respondents hence remain unexploited. With respect to the territories, farmers in Bambesa and Buta do not consume yam in any other form than boiled form which maybe attributable to the challenge of low tuber quality prevalence in these territories. Farmers in Bumba reported four forms of consumption (boiled yam=33\%; grilled yam $=25 \%$; pounded yam $=22 \%$; fried yam $=19$ ). This territory has some of the best landrace varieties of yams in the survey regions. Farmers in Lisala reported three form of consumptions however preference was placed on two (boiled yam $=\sim 58 \%$ and pounded yam $=41 \%$ ). Farmers in Isangi reported four forms of consumption with higher preference for boiled yam (84\%) compared to other forms.

\section{Table 11: Farmers preference criterial and their utilization}


Category

Bas-Uélé province

Mongala province

Tshopo province

$\begin{array}{lllllll}\text { Bambesa } & \begin{array}{l}\text { Buta } \\ \mathrm{n}=90\end{array} & \begin{array}{l}\text { Bumba } \\ \mathrm{n}=90\end{array} & \begin{array}{l}\text { Lisala } \\ \mathrm{n}=90\end{array} & \begin{array}{l}\text { Kisangani } \\ \mathrm{n}=90\end{array} & \begin{array}{l}\text { Isangi } \\ \mathrm{n}=90\end{array} & \begin{array}{l}\text { Total } \\ \mathrm{n}=540\end{array}\end{array}$

$\mathrm{n}=90$

\section{Yam selection criteria}

(\%)

\begin{tabular}{llllllll}
$\begin{array}{l}\text { Good tuber quality (e.g. } \\
\text { Taste) }\end{array}$ & 50.00 & 57.42 & 47.62 & 59.46 & 46.77 & 55.90 & 52.86 \\
\hline High yield & 50.00 & 41.93 & 47.62 & 30.41 & 16.13 & 41.61 & 37.95 \\
\hline Earliness & - & 0.65 & - & 2.03 & 37.10 & 2.48 & 7.04 \\
\hline Prolong shelf life & - & - & 3.87 & 4.05 & - & - & 1.32 \\
\hline Ease of harvesting & - & - & - & 2.03 & - & - & 0.34 \\
\hline Ease of processing & - & - & 1.94 & 2.03 & - & - & 0.66
\end{tabular}

Form for consumption

(\%)

\begin{tabular}{llllllll}
\hline Boiled form & 100.00 & 100.00 & 33.46 & 57.69 & 78.26 & 84.11 & 75.59 \\
\hline Pounded form & - & - & 22.43 & 41.03 & - & 4.67 & 11.36 \\
\hline Grilled form & - & - & 25.10 & 1.28 & 17.39 & 6.54 & 8.39 \\
\hline Fried form & - & - & 19.01 & - & 4.35 & 4.67 & 4.67 \\
\hline
\end{tabular}

Value added form (e.g.

cake)

\subsection{Discussions}

\subsection{Diversity, Classification and Genetic resource management of yams (Dioscorea spp) in DR Congo}

The variation in the quantity of landrace clones at the household level could be attributed to agro-ecology, climatic and human factors that support some Dioscorea species in some provinces than the others. For example, the highest number of landrace clones in the Bas-Uélé province is half of the quantity in Mongala and Tshopo provinces. Also, all the five species of yam were only present in Tshopo province. Nevertheless, that this study observed five different species of Dioscorea, we cannot totally ascertain that all the landrace varieties within each Dioscorea species observed are truly genetically distinct due to the possibility of linguistic polymorphism. Hence, the possibility that this study has underestimated or overestimated the actual number of landraces present in our study areas cannot be ruled out. Similar studies have also reported the influence of linguistic polymorphism in bush yam in the central region of Ghana [27]; bitter yam in Benin [28], [29]; and Dioscorea species in Southern Ethiopia [10]. The proposed challenge with linguistic polymorphism in this study could be easily clarified with further study on morphological and molecular characterization of the different landrace varieties observed. 
Shannon-Wiener diversity index [30] index revealed a moderate level of diversity in Dioscorea species which could possibly support the collection and conservation of yam germplasm for future use. Of the provinces used for this study, Tshopo and Mongala provinces have similar level of diversity (more species of yams and morphotypes) compare to the province of Bas-Uélé. This could be attributed to the vegetation type (forest zone), higher rainfall, higher relative humidity and closeness to the Congo river. On the other hand, Bas-Uélé province is located in the transition zone (partly influenced by the Savannah). Increase in the diversity of Dioscorea species existing in the forest has also been reported by [31], [32] in Togo and [33] in cultivated species in Ghana. The closeness to the Congo river is an identification marker popularly used by the Congolese to identify areas where yams are cultivated or found in the country. Thus, possibly providing the opportunity for domestication of yams by farmers. Scarcelli et al. [12] inferred that the origin and expansion of African yam agriculture also started in the Niger river basins.

Our study further showed that an increase in yam cultivation experience and age range increases the familiarity of the farmers with the characteristics of their varieties. Hence, farmers can better identify the varieties unsafe for consumption, with good agronomic and tuber qualities from their germplasm. This relationship confirms previous study by Andriamparany et al. [34] on the study of wild yam in western Madagascar. An increase in the farm size would increase the quantity of yam cultivated thus, increasing yam production and productivity. This relationship is in contrary to the findings of Tamiru et al. [10] where no correlation was reported on the study of yam landraces in southern Ethiopia. Larger family size will provide more workforce for yam farming activities.

The maturity class of the existing yam genetic resources is mostly late maturity. This is so because the yams in DR Congo has never undergone any major scientific improvement through breeding and selection except for domestication by farmers. Even with the presence of the National Agricultural Study and Research Institute (INERA) and numerous higher institutions, yams have received insignificant attention with respect to genetic improvement resulting in some landraces extinction. Such programs could have assisted in proper collection, documentation, and conservation of yam genetic resources to prevent loss of genepools. Farmers reported 14 landrace varietal names across the study areas that have been abandoned either in cultivation or usage primarily due to poisons. D. bulbifera has been most implicated in this regard as pointed out by the farmers. However, not all the morphotypes in this species are poisonous as it is still being consumed by some people as observed during the survey. The question remains the proper differentiation of the morphotypes safe for consumption from the genepool. Modern breeding techniques such as detailed morphological characterization, molecular tools (DNA markers e.g. SSRs and SNPs) and DNA sequencing could help to tackle this challenge.

\subsection{Constraints to yam (Dioscorea spp.) production and productivity in DR Congo}

The major challenge observed with the yams in DR Congo is the tuber quality attributes (poor post-harvest shelf life, high tuber flesh oxidation, poor taste, and rapid tuber hardiness). The has largely discouraged a lot of farmers from the cultivation of yams, affected market demand leading to poor pricing by the consumers. Thus, reducing farmers profit margins. This has also affected the consumption pattern of yams by the populace. This is in contrast to the turn of events with the other competitive stable food crops (cassava, maize and sweet potato) in the country. These crops have received an appreciable amount of improvement and famers have largely adopted the varieties and gradually being used to replace yam fields in many parts of the country. The influence of tuber quality on the adoption and abandonment of yams has also been reported in many studies. For example, It was reported as a contributing factor to loss of yam genetic resources [35] as well abandonment of bush yam [31] in Togo.

Though yam improvement program is lacking in DR Congo, domestication effort by farmers have played a little role in improving some landrace varieties (better taste and reduced flesh oxidation). This was observed in Bumba and

Page 25/34 
Kisangani territories. However, production is far from sufficient. With these two partly addressed by farmers, poor post-harvest shelf life and rapid tuber hardiness remained issues that require urgent breeding intervention. Other limiting factors observed were difficulty in harvesting, poor soil, and harvest pest (insects). Majority of the farmers make use of cutlasses and spades for harvesting yam. These tools often cause injuries to the farmers during harvesting as well as tubers (bruises and cuts) especially with irregular form tubers. Tuber injury may be the major precursor to the poor post-harvest shelf life as it serves as the entry point for disease pathogens.

The intercropping system practiced by the majority of farmers and low use of soil amendment and fertilizers contributes to poor soils. This system if not well planned as the case observed during the survey, could result in high pressure on the soil with respect to nutrient uptake by the crops. During the planting season, the insect pests belonging to the beetle and the termite families constantly threaten yam tubers especially during harvest. Termites have also being reported to cause serious damage to yam fields in central Benin [36]. Difficulty in harvesting, poor soil, and pests were also listed as constraints to yam production and productivity in Nigeria [1]. This study therefore proposes the screening for susceptibility to insect attacks using morphological and molecular tools as a means to provide insight into insect pest resistance in DR Congo yam germplasm.

\subsection{Yam cultivation, cultural practices and farmers' preference criterial for selection and utilization of yams in DR Congo}

The importance of yam in contributing to household food security and income generation was observed in our study. Yam has also been found to contributes substantially to household food security in Ghana [4], [37]; in Nigeria [1]; in Benin [29]; and in Ethiopia [10]. Medicinal value of yam has not been exploited like reported in other countries [29], [38].

Yam tubers are mostly consumed in boiled form by the populace which is the same as the form of consumption in many yam producing countries due to the simplicity in preparation. Similar observation was reported for Dioscorea dumetorum in Benin [29] and Dioscorea rotundata in Nigeria [9]. Yam value addition remains alien to many people probably due to the lack of the knowledge with respect to various processing forms that results in value addition to yam.

The association cropping system practiced by farmers allows the opportunity to meet nutritional demands and provide easy yam stakes in the case of maize and cassava. Thus, reducing staking demand of yam. Though the use of stakes to support yam has not been well adopted as many farmers prefer yam cultivation without staking due to the hardship involved. Staking is the yam producers main concern. In the absence of non-staked yam variety, cultivation of yams without staking has been found to reduce yield production by 33\% [39] and a minimum of $59 \%$ [40] confirming the importance of this practice in yam production. Staking importance cannot be overemphasized. Staking permits easy weeding of the field, reduces weed growth and enhances better canopy formation [40]. Therefore, yam producers need to be sensitized on the importance of staking to facilitates the adoption and to boost their production capacity. Similarly, farmers practicing the use of individual plant staking with wooden stick should also be advised on the use of minimum staking (trellis method). This system of staking minimizes the drudgery in staking individual plant and the rate of environmental degradation resulting from deforestation by farmers in search of wooden sticks [39].

The inability of the farmers to practice double harvesting results in loss of opportunity to generate seeds (seedyam) for subsequent planting seasons. Double harvesting provide the opportunity to have milked tuber and seedyam. Thus, reduces the involvement of harvested tubers as seedyam for the following season [9], cost of production and 
increases profit margin. Following harvesting, most farmers prefer to store their produces to prevent yam glut in the market. This most times lead to increase in the price of market yam following increased demand. Sometimes farmers also suffer tuber loss during storage consequently forcing up the price of yam in the market.

Farmers' preference criterial for selection and utilization of yams in DR Congo are: good taste and non-oxidizing tuber flesh color (tuber quality), high yield and earliness. Thus, establishing a yam improvement program to assist the development of new and improved varieties of existing yams for the yam producers should put these criterial into consideration. According to the farmers, realization of these criteria will spark a new line of interest in the mind of many farmers. Especially non-yam producers and those who have abandoned yam for other crops. Good tuber quality was also suggested to enhance the marketability and cultivation of yams [31]. A rapid method for breeding for improvement in tuber quality of yams is the use of Near Infrared Reflectance Spectrophotometry (NIRS). The NIRS system is advantageous compare to the conventional methods mostly employed to determine the physico-chemical properties of yams with respect to time and cost reduction [41]-[43]. Thus, screening the landrace germplasms identified by this study for the selection for clones with good tuber quality to address the urgent need of the yam farmers could be facilitated.

\subsection{Seedyam production system in DR Congo}

The practice of generating seedyam from previous harvests is a common phenomenon for seasonal yam cultivators. Farmers also engage in trade by batter which is a system of changing other food crops for seedyam for field establishment. This is commonly the case for new yam farmers who lack enough money to purchase tubers from the market. The current methods of obtaining seedyam has contributed to the inadequacy of seeds availability and viability. This may be due to high loss of tubers during storage before the next planting season.

The modern practice of seedyam production does not exist in DR Congo as farmers practice the conventional system of using yam-setts as seedyam. This system is currently putting the yam producers in at a disadvantage unknown to many of the farmers. Considering the weight of the yam setts used for cultivation, lack of the knowledge and zeal to practice double harvesting [44], and high tuber losses due to poor storage. Different methods of generating seedyam have been researched and proposed to yam farmers in many yam producing countries. These methods include, the mini-sett system, the vine cutting, the tissue culture system, the aeroponics system [44], and the semi-autotropic hydroponic system (SAH) [45]. Of these methods, the miniset system appeared to be most successfully adopted by farmers in many yam producing countries [44] giving a positive hope for adoption by yam farmers in DR Congo. This will aid the development of viable seedyam supply systems for multiplying and distributing the seed yams to the farmers.

\subsection{Conclusion}

The study revealed a moderate diversity for yams across five different species in DR Congo. The diversity was relatively higher in Tshopo and Mongala provinces than Bas-Uélé province. The principal challenges limiting yam production in DR Congo surrounds the tuber quality attributes (poor post-harvest shelf life, tuber oxidation, poor taste, and rapid tuber hardiness) of the available varieties. Yam cultivation is targeted to meet the food and financial demands of the populace. Yam farmers preferred yams varieties with good tuber qualities, high yield and early maturing varieties. In the absence of formal seedyam production practice, farmers practiced the system of producing seeds by themselves as well as informal exchange of seeds with neighbors and friends. The establishment of a yam improvement program to meet farmers' selection criteria, collection and conservation of yam germplasm into genetic

Page 27/34 
resources, and the development of an effective seed delivery system to meet the seed availability and viability needs could increase yam production and profitability in DR Congo.

\section{Declarations}

\section{ETHICS APPROVAL AND CONSENT TO PARTICIPATE}

Not applicable.

\section{CONSENT FOR PUBLICATION}

Not applicable.

\section{AVAILABILITY OF DATA AND MATERIALS}

Data can be obtained upon request from the corresponding author.

\section{COMPETING INTEREST}

The authors declare that the research was conducted in the absence of any potential conflict of interest.

\section{FUNDING}

The African trans-regional cooperation through Mobilité Université en Afrique (MOUNAF) project funded by the European Union Commission within the framework of "Intra Africa Mobility Scheme" granted a Ph.D. scholarship to the first author to study at the University of Kisangani, DR Congo. This study is also partially supported by the BMGF under the AfricaYam project and publication fees will be covered by the BMGF.

\section{AUTHOR CONTRIBUTIONS}

Conceptualization, I.I.A., D.O.O., P.A.A., J.G.A. and J.M.L. Methodology, I.I.A. and P.A.A.; Data analysis, I.I.A., P.A.A.; Supervision, D.O.O., P.A.A., and J.G.A.; Writing original draft, I.I.A. ad P.A.A.; Manuscript review and editing, I.I.A., P.A.A., D.O.O., J.G.A., J.M.L., I.M.C and J.LK.

\section{ACKNOWLEDGEMENT}

Authors acknowledge the provision of research fund to the first author by the MOUNAF project. Directorate of Research and finance office of the University of Kisangani is also acknowledged for managing the MOUNAF project. We appreciate the guidance the inspector of the Inspection Provinciale de l'Agriculture, the cooperation of all yam local farmers and local aids and authorities that facilitated data collection at the six territories used for the study. We also thank all other PhD colleagues within the project and the department for their motivational supports.

\section{References}

[1] E. E. Bassey, "Constraints and Prospects of Yam Production in Nigeria," Eur. J. Phys. Agric. Sci., vol. 5, no. 1, pp. 55-64, 2017, [Online]. Available: www.idpublications.org.

[2] R. Asiedu and A. Sartie, "Crops that feed the World 1. Yams," Food Secur., vol. 2, no. 4, pp. 305-315, 2010, doi: 10.1007/s12571-010-0085-0. 
[3] O. Emmanuel, A. Richard, M. Kolesnikova-Allen, and A. Robert, "Ethno-botany and morphological characterisation of the yam pona complex in Ghana," Crop Sci., vol. 9, no. November 2014, pp. 407-414, 2009.

[4] L. Kenyon and M. Fowler, "Factors affecting the uptake and adoption of outputs of crop protection research on yams in Ghana," vol. 7504, no. June, pp. 15-25, 2000.

[5] D. G. Coursey, "Yams: an account of the nature, origins, cultivation and utilisation of the useful members of the Dioscoreaceae," Science (80-. )., vol. 163, 1967.

[6] S. K. Hahn, D. S. O. Osiru, M. O. Akoroda, and J. A. Otoo, "Yam production and its future prospects. Outlook on Agriculture," Outlook Agric., vol. 16, no. 3, pp. 105-110., 1987.

[7] B. A. Adejumo, R. O. Okundare, O. I. Afolayan, and S. A. Balogun, "Quality attributes of yam flour (Elubo) as affected by blanching water temperature and soaking time," Int. J. Eng. Sci., vol. 2, no. 1, pp. 216-221, 2013.

[8] H. D. Mignouna, M. M. Abang, R. Asiedu, and R. Geeta, "True yams (dioscrea): A biological and evolutionary link between eudicots and grasses," Cold Spring Harb. Protoc., vol. 4, no. 11, pp. 1-8, 2009, doi: 10.1101/pdb.emo136.

[9] B. Nkamleu, D. Annang, and N. M. Bacco, Securing Livelihoods through Yams, no. September. 2009.

[10] M. Tamiru, H. C. Becker, and B. L. Maass, "Diversity, distribution and management of yam landraces (Dioscorea spp.) in Southern Ethiopia," Genet. Resour. Crop Evol., vol. 55, no. 1, pp. 115-131, 2008, doi: 10.1007/s10722-007-9219-4.

[11] H. D. Mignouna and A. Dansi, "Yam (Dioscorea ssp.) domestication by the Nago and Fon ethnic groups in Benin," Genet. Resour. Crop Evol., vol. 50, no. 5, pp. 519-528, 2003, doi: 10.1023/A:1023990618128.

[12] N. Scarcelli et al., "Yam genomics supports West Africa as a major cradle of crop domestication," Sci. Adv., vol. 5, no. 5, pp. 1-8, 2019, doi: 10.1126/sciadv.aaw1947.

[13] N. Scarcelli et al., "Genetic nature of yams (Dioscorea sp.) domesticated by farmers in Benin (West Africa)," Genet. Resour. Crop Evol., vol. 53, no. 1, pp. 121-130, 2006, doi: 10.1007/s10722-004-1950-5.

[14] K. Mbuya, K. K. Nkongolo, and R. Kizungu, "Participatory selection and characterization of quality protein maize ( QPM ) varieties in Savanna agro- ecological region of DR-Congo," J. Plant Breed. Crop Sci., vol. 2, no. 11, pp. 325-332, 2010.

[15] K. K. Nkongolo, K. Mbuya, M. Mehes-Smith, and A. Kalonji-Mbuyi, "Molecular analysis of quality protein (QPM) and normal maize varieties from the DR-Congo breeding program," African J. Biotechnol., vol. 10, no. 65, pp. 14293-14301, 2011, doi: 10.5897/ajb11.1491.

[16] J. Walangululu et al., "Performance of introduced irrigated rice varieties in Ruzizi plain , South Kivu province , DR Congo Résumé," vol. 9, no. September, pp. 1631-1636, 2012.

[17] G. R. Kombo et al., "Diversity of cassava (Manihot esculenta Crantz) cultivars and its management in the department of Bouenza in the Republic of Congo," Genet. Resour. Crop Evol., vol. 59, no. 8, pp. 1789-1803, 2012, doi: 10.1007/s10722-012-9803-0. 
[18] R. S. Kawuki et al., "Genetic diversity of cassava (Manihot esculenta Crantz) landraces and cultivars from southern, eastern and central Africa," Plant Genet. Resour. Characterisation Util., vol. 11, no. 2, pp. 170-181, 2013, doi: $10.1017 / S 1479262113000014$.

[19] I. H. Burkill, "Notes on the Genus Dioscorea in the Belgian Congo," Bull. du Jard. Bot. l'État a Bruxelles, vol. 15, no. 4,1939 , doi: $10.2307 / 3666821$.

[20] J. Magwé-Tindo, L. Zapfack, and B. Sonké, “Diversity of wild yams (Dioscorea spp., Dioscoreaceae) collected in continental Africa," Biodivers. Conserv., vol. 25, no. 1, pp. 77-91, 2016, doi: 10.1007/s10531-015-1031-4.

[21] M. V. Siqueira, G. Dequigiovanni, M. A. Corazon-Guivin, J. C. Feltran, and E. A. Veasey, “DNA fingerprinting of water yam (Dioscorea alata) cultivars in Brazil based on microsatellite markers," Hortic. Bras., vol. 30, no. 4, pp. 653659, 2012, doi: 10.1590/s0102-05362012000400015.

[22] F. Bukatuka et al., "Bioactivity and Nutritional Values of Some Dioscorea Species Traditionally Used as Medicinal Foods in Bandundu, DR Congo," European J. Med. Plants, vol. 14, no. 1, pp. 1-11, 2016, doi: 10.9734/ejmp/2016/25124.

[23] M. Hoogendijk and D. E. Williams, "Characterizing the genetic diversity of home garden crops: some examples from the Americas.," in Home gardens and in situ conservation of plant genetic resources in farming systems, 2002.

[24] INS, INS Annuaire statistique 2014. Institute National de la Statistiqu. Ministère du Plan et Révolution de la modernité, 2015.

[25] W. Taiyun and S. Viliam, “R pakage 'corrplot': Visualization of a Correlation Matrix." 2021, [Online]. Available: https://github.com/taiyun/corrplot.

[26] M. Maechler, P. Rousseeuw, A. Struyf, M. Hubert, and K. Hornik, "cluster: Cluster Analysis Basics and Extensions. R package." 2019.

[27] A. S. Adewumi, K. J. Taah, P. A. Asare, M. O. Adu, and P. A. Agre, "Assessment of Genetic Diversity of Dioscorea praehensilis (Berth.) Collected from Central Region, Ghana using Simple Sequence Repeat (SSR) Markers," J. Agri. Curr. Res., vol. 1(1), no. March, p. 1005, 2020.

[28] J. Laly, D. S. J. C. Gbemavo, A. A. Gbaguidi, I. Dossou-Aminon, and A. Dansi, "Dioscorea dumetorum (Kunth) Pax, a neglected and underutilized yam species in Benin: folk classification and post-harvest conservation," Genet. Resour. Crop Evol., vol. 66, no. 4, pp. 965-979, 2019, doi: 10.1007/s10722-019-00762-0.

[29] F. A. Adigoun-Akotegnon, H. Adoukonou-Sagbadja, C. Fadinan, A. Tchougourou, M. Agassounon-Tchibozo, and C. Ahanhanzo, "Diversity, distribution and ethnobotanical importance of cultivated and wild African trifoliate yam [Dioscorea dumetorum (Kunth) Pax] in Benin," Genet. Resour. Crop Evol., vol. 66, no. 3, pp. 659-683, 2019, doi: 10.1007/s10722-019-00739-z.

[30] C. E. Shannon, "A Mathematical Theory of Communication,” Bell Syst. Tech. J., 1948, doi: 10.1002/j.15387305.1948.tb01338.x.

[31] W. E. N. Pitalounani et al., "Agrodiversity, peasant management and importance of Dioscorea praehensilis Benth. In the Subhumid Zone of Togo," African J. Food, Agric. Nutr. Dev., 2017, doi: 10.18697/ajfand.79.15930. 
[32] A. Gnamkoulamba, W. Tchala, S. Tostain, and I. Soumana, "Le bayere, une forme domestiquee de dioscorea praehensilis dans la prefecture de wawa (togo)," Ann. des Sci. Agron., 2009, doi: 10.4314/asab.v3i2.43382.

[33] E. Otoo, M. Opoku Agyeman, A. Dansi, L. M. Aboagye, K. Acheremu, and J. P. Tetteh, "Increasing farmers and breeders access to yam (Dioscorea spp) diversity: The case of Forest-Savannah Transition Agroecology," African J. Agric. Res., vol. 10, no. 8, pp. 772-782, 2015, doi: 10.5897/ajar2014.8850.

[34] J. N. Andriamparany, K. Brinkmann, V. Jeannoda, and A. Buerkert, "Effects of socio-economic household characteristics on traditional knowledge and usage of wild yams and medicinal plants in the Mahafaly region of south-western Madagascar," J. Ethnobiol. Ethnomed., vol. 10, no. 1, 2014, doi: 10.1186/1746-4269-10-82.

[35] A. Dansi et al., "Varietal diversity and genetic erosion of cultivated yams (Dioscorea cayenensis Poir - D. rotundata Lam complex and D. alata L.) in Togo," Int. J. Biodivers. Conserv., vol. 5, no. 2, pp. 223-239, 2013, doi: 10.5897/IJBC12.131.

[36] Y. L. Loko et al., "Farmers' knowledge and perceptions of termites as pests of yam (Dioscorea spp.) in Central Benin," Int. J. Pest Manag., vol. 62, no. 1, pp. 75-84, 2016, doi: 10.1080/09670874.2015.1107151.

[37] L. M. Aboagye, D. Nyadanu, M. O. Opoku Agyeman, S. K. Owusu, and E. Asiedu Darko, "Survey of diversity and production of yams in four communities in Southern Ghana," African J. Agric. Res., vol. 10, no. 24, pp. 24532459, 2015, doi: 10.5897/ajar2014.9468.

[38] D. Fan et al., "Agro-ecological suitability assessment of Chinese Medicinal Yam under future climate change," Environ. Geochem. Health, vol. 42, no. 3, pp. 987-1000, 2020, doi: 10.1007/s10653-019-00437-w.

[39] S. . Ennin, R. . Issaka, P. . Acheampong, M. Numafo, and E. . Danquah, "Mechanization, fertilization and staking options for environmentally sound yam production," African J. Agric. Res., vol. 9, no. 29, pp. 2222-2230, 2014, doi: 10.5897/ajar2014.8487.

[40] E. K. Tsado, "Substituting wooden sticks with plastic stakes in yam production in in Niger State , Nigeria .," vol. 2, no. 9, pp. 88-97, 2012.

[41] O. E. Alamu, M. Adesokan, and B. Maziya-Dixon, “Calibration development for nutritional evaluation of Yam (Dioscorea sp.) using Near-Infrared Reflectance Spectrophotometry (NIRS)," Cogent Chem., vol. 5, no. 1, p. 1565623, 2019, doi: 10.1080/23312009.2019.1565623.

[42] E. O. Alamu, M. Adesokan, A. Asfaw, and B. Maziya-Dixon, "Effect of sample preparation methods on the prediction performances of near infrared reflectance spectroscopy for quality traits of fresh Yam (Dioscorea spp.)," Appl. Sci., vol. 10, no. 17, 2020, doi: 10.3390/app10176035.

[43] V. Lebot and R. Malapa, "Application of near infrared reflectance spectroscopy for the evaluation of yam (Dioscorea alata) germplasm and breeding lines," J. Sci. Food Agric., vol. 93, no. 7, pp. 1788-1797, 2013, doi: 10.1002/jsfa.6002.

[44] B. A. Aighewi, R. Asiedu, N. Maroya, and M. Balogun, "Improved propagation methods to raise the productivity of yam (Dioscorea rotundata Poir.)," Food Secur., vol. 7, no. 4, pp. 823-834, 2015, doi: 10.1007/s12571015-0481-6. 
[45] P. Olugboyega et al., "Semi-Autotrophic Hydroponics: A potential seed system technology for reduced breeding cycle and rapid quality seed delivery," 2019. doi: 10.13140/RG.2.2.33676.77449.

\section{Figures}

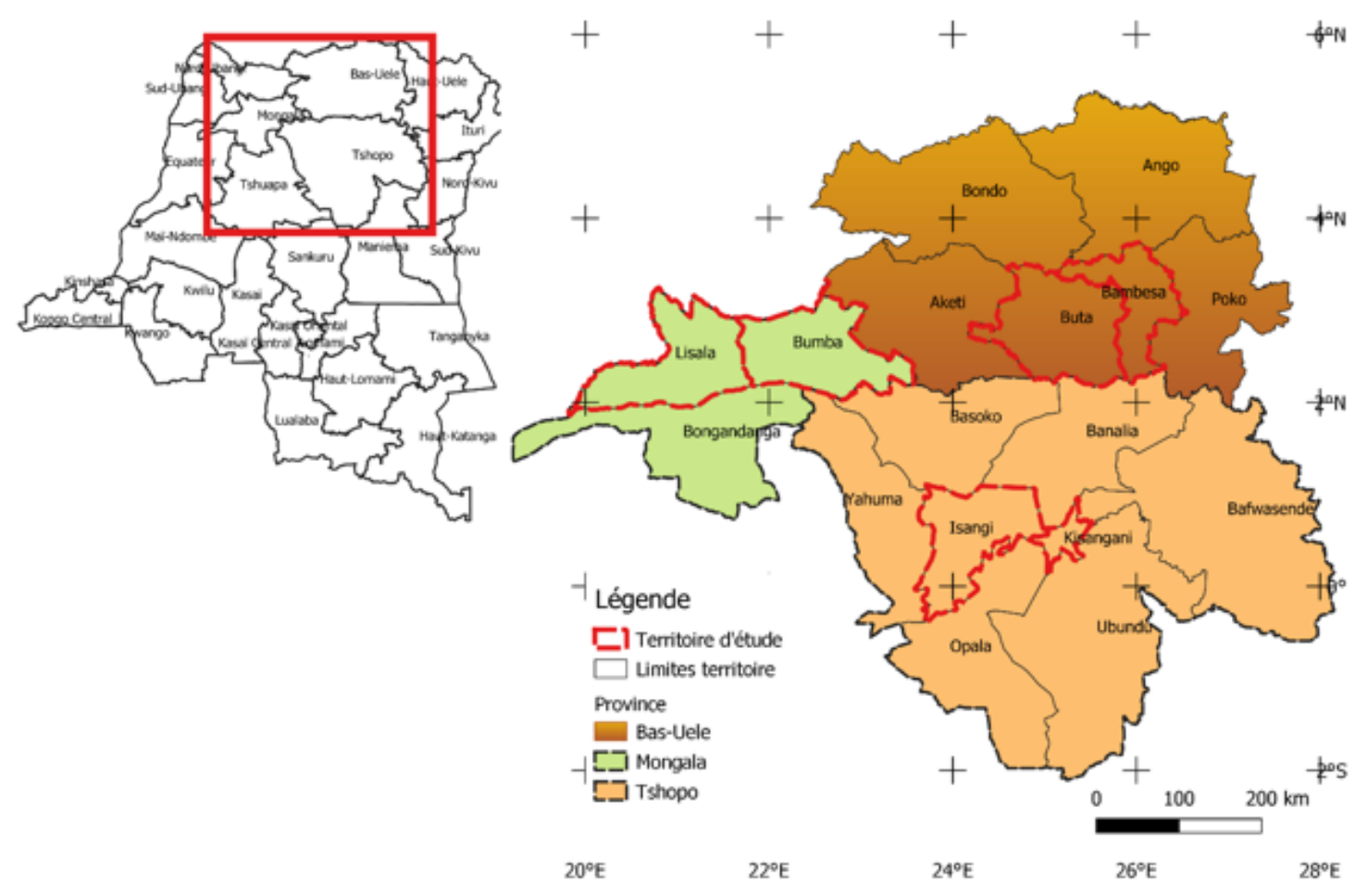

\section{Figure 1}

Map of DR Congo showing the six territories from the three provinces representing the study area.

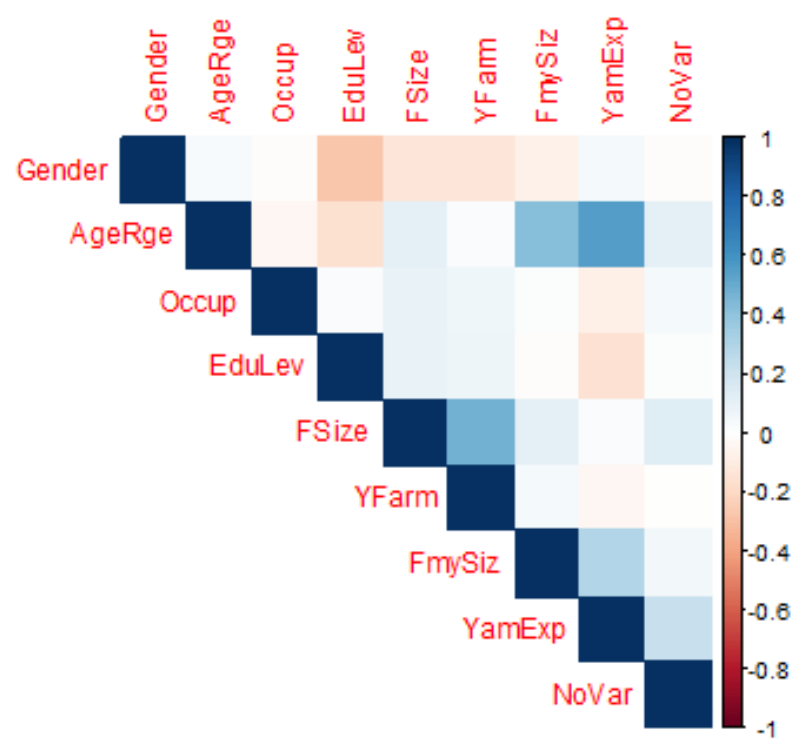

\section{Figure 2}

Correlation coefficients between the different Dioscorea spp cultivated at household and socio-demographic parameters. AgeRge: Age range, Occup: Occupation, EduLev: Educational level, FSize: Farm size, YFarm: Yam farm 
size, FmySiz: Family size, YamExp: Yam cultivation express, NoVar: Number of landrace cultivated (please remove religion and marital status from the graph

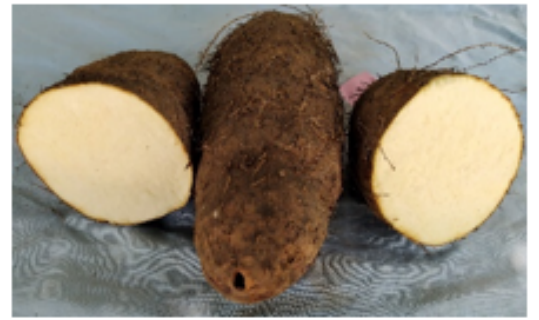

Ekolo (Dioscorea alata)

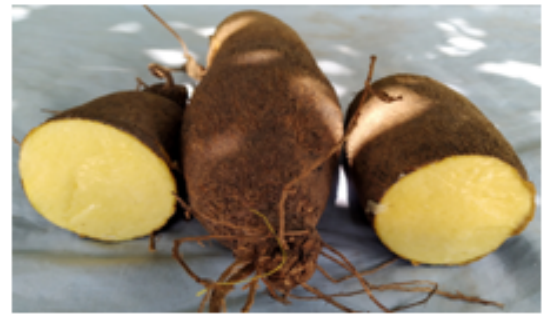

Abuluka (Dioscorea cayenensis)

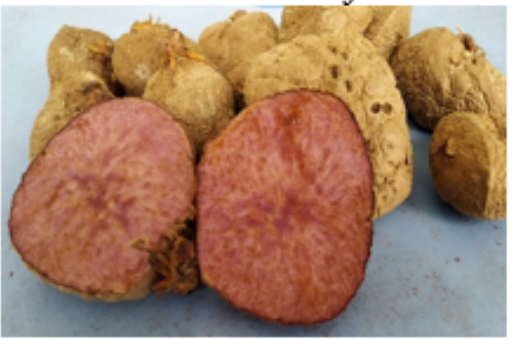

Litehu (Dioscorea bulbifera)

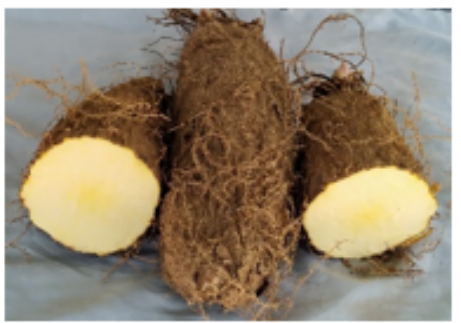

Wasalaka (Dioscorea rotundata)

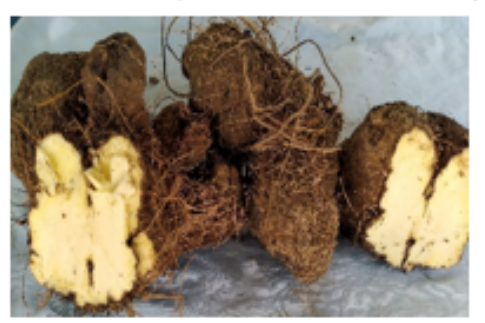

Bilenge (Dioscorea dumetorum)

\section{Figure 3}

Some yam genotypes from the five yam species identified across the study areas 

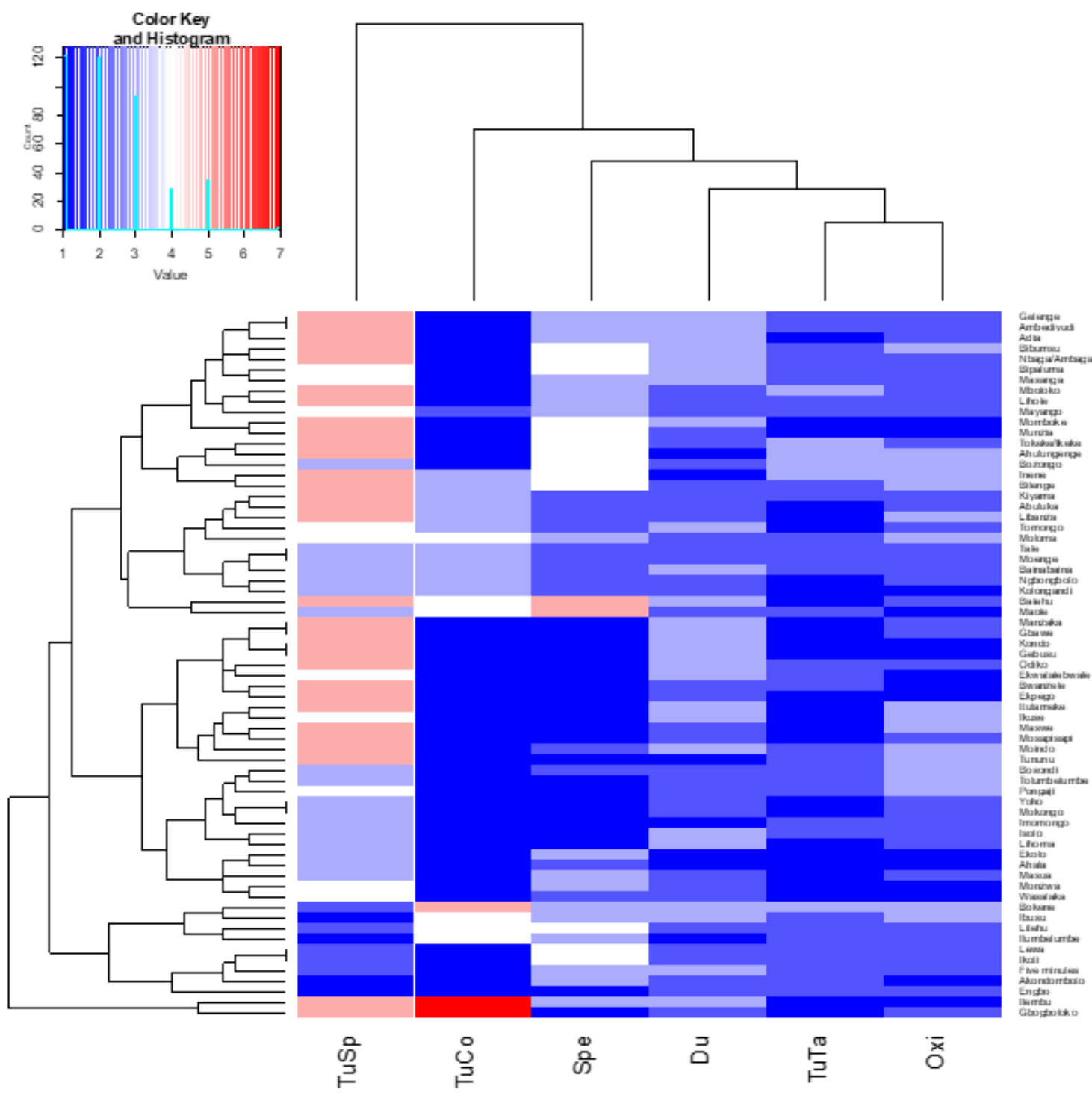

Figure 4

Dendrogram presenting the classification of yam (Dioscorea species) based tuber qualities traits 